DIW BERLIN

Discussion

Papers

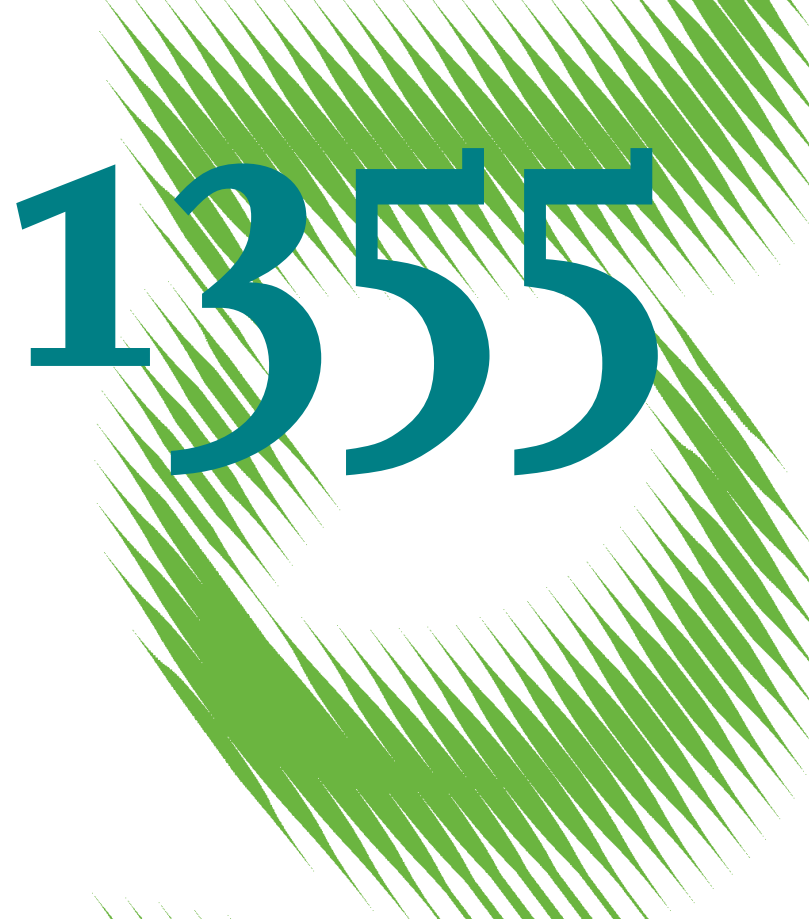

Too Rich to Do the Dirty Work?

Wealth Effects on the Demand for Good Jobs 
Opinions expressed in this paper are those of the author(s) and do not necessarily reflect views of the institute.

IMPRESSUM

(C) DIW Berlin, 2014

DIW Berlin

German Institute for Economic Research

Mohrenstr. 58

10117 Berlin

Tel. $+49(30) 89789-0$

Fax +49 (30) $89789-200$

http://www.diw.de

ISSN print edition $1433-0210$

ISSN electronic edition 1619-4535

Papers can be downloaded free of charge from the DIW Berlin website:

http://www.diw.de/discussionpapers

Discussion Papers of DIW Berlin are indexed in RePEc and SSRN:

http://ideas.repec.org/s/diw/diwwpp.html

http://www.ssrn.com/link/DIW-Berlin-German-Inst-Econ-Res.html 


\title{
Too rich to do the dirty work? Wealth effects on the demand for good jobs
}

\author{
Luke Haywood *
}

2nd January 2014

\begin{abstract}
Jobs offer different wages and different non-monetary working conditions. This paper investigates how the demand for non-monetary aspects evolves over changing wealth levels. Wages do not perfectly compensate individuals for differential utility of jobs in a labour market with informational frictions. Changes in wealth may then affect preferences for different jobs. Willingness to pay for non-monetary aspects of jobs (measured by job satisfaction for work "in itself") is found to increase with wealth shocks. Duration models are estimated based on the reduced form of a search model. Wealth may play an important role in labour market choices.
\end{abstract}

JEL: J21,J28,J32,J64

Keywords: labor supply, wealth, job satisfaction, duration models.

*DIW Berlin, Mohrenstrasse 58,10117 Berlin, LHaywood@diw.de. Subject to the usual disclaimer I would like to thank Andrew Clark, Jean-Marc Robin, Antoine Terracol and conference and seminar participants in Paris, Dubrovnik, Rome, Angers, Marseille and Oslo for helpful comments. 
Job quality, search and wealth

\section{Introduction}

Differences in wealth have recently reached high levels ${ }^{1}$, and yet the influence of wealth in the labour market has only been considered in a very simple model in which working homogeneously decreases workers' utility. The labour supply effects of changes in wealth arise as costly effort (in a job) is reduced in favour of pleasurable leisure. As a result, wealth unambiguously decreases labour supply.

In a more general setting, jobs are associated with different levels of utility and include monetary and non-monetary dimensions - jobs have high or low wages and are more or less intrinsically pleasurable ${ }^{2}$. In line with diminishing marginal utility of consumption, the non-monetary aspects may be expected to become more important with increasing wealth. The labour supply effect of changes in wealth will then depend on the balance of monetary and non-monetary benefits of a specific job as richer individuals move away from jobs with little non-monetary value ${ }^{3}$. Taking into account wealth as well as non-monetary dimensions should be important in terms of welfare measures of the labour market - e.g. the inequality of labour market outcomes may be much larger than the inequality of income suggests.

Changes in wealth are often accompanied by other changes relevant for individuals' labour supply. Individuals may save as a result of a spouse losing their job or as a result of a pregnancy. Most changes in wealth are thus related in complicated ways to individual behaviour and circumstances, making estimation of wealth effects on preferences for job characteristics difficult. The empirical strategy of this article thus uses information on windfall gains (mainly from lottery winnings and inheritances) as instruments for wealth changes. These windfalls are expected not to be caused by labour market behaviour and thus provide an original source of identification for the effect of wealth on workers' job preferences - a question that has apparently not been studied in the literature so far.

This article is organised as follows: Section (3) presents a model of job search from which we derive testable predictions for the reduced form relationship between exogenous changes in wealth ${ }^{4}$, wages, working conditions and the rate of

\footnotetext{
${ }^{1}$ As Piketty (2009) argues in a recent study on the evolution of inheritance in France

${ }^{2}$ Many factors may determine the non-monetary value of a particular job, and this paper does not attempt to identify what causes a job to have high non-monetary value.

${ }^{3}$ Note that we do not obtain this prediction if the labour market is characterized by complete compensating differentials, implying that all jobs have the same value to all individuals. However, this would require not only perfect information about available jobs but - following the argument of this paper - also wage-discrimination according to workers' wealth levels.

${ }^{4}$ Appendix (C) considers the difficulty involved in moving to a job search framework that allows
} 
Job quality, search and wealth

job quitting. Section (4) introduces the British household panel which provides information on job durations, job characteristics as well as workers' windfall gains. Section (5) presents our estimation strategy based on duration data and presents two estimators with a focus on their treatment of heterogeneity, duration dependency, and how we try to relax parametric restrictions in these areas respectively. Results are presented in section (6). The impact of changes in wealth on raising marginal willingness to pay for non-monetary job characteristics is demonstrated. For individuals who move between jobs, section (7) traces the evolution of wages and working conditions in the destination job where this information is available. Section (8) concludes.

\section{Wealth and the search for good jobs}

This section considers the relationship between wages and non-monetary job characteristics, focusing on search theories of the labour market before introducing the role of wealth.

The extent to which wage determination is influenced by non-monetary (often called "hedonic") factors has interested economists since Adam Smith formulated the basic prediction that employers would have to pay workers more to fulfill less satisfying tasks. Rosen (1986) shows that under certain conditions, preferences for job characteristics can be recovered from the wage differentials that workers accept for jobs with different conditions. This spurned a large literature estimating "hedonic wage regressions" with mixed success 5 .

\subsection{Job satisfaction and job search}

Several reasons may be put forward to explain why wages may not compensate for differential working conditions, e.g. workers with different tastes may sort into jobs with different attributes (Kniesner et al. (2012)). This article focuses on the fact that in a labour market with limited information on job offers, firms use their market power and job characteristics are not priced competitively (Hwang et al. (1998)), i.e. wages do not completely compensate workers for differences in non-monetary working conditions. This is in line with the finding that job satisfaction reduces job turnover rates (early papers are Hamermesh (1977) and Freeman

for endogenous accumulation of wealth.

${ }^{5}$ Aldy and Viscusi (2003) critically review studies on the most well-researched dimension of working conditions, the risk of fatal injury. 
Job quality, search and wealth

(1978), more recently Clark (2001)). Different strategies have tried to assess preferences for job characteristics without relying on hedonic wage regressions.

Bonhomme and Jolivet (2009) exploit the fact that some job mobility is involuntary to argue that this can help identify the marginal willingness to pay for good job characteristics.

A second strategy focuses on the fact that simple job search models predict that the optimal strategy for workers engaged in on-the job-search is to compare the utility of their current job to the level of utility in an alternative job ${ }^{6}$. Gronberg and Reed (1994) show that in this setting, identification of workers' marginal willingness to pay for job amenities is ensured if we have information on job durations as well as on wages and job characteristics. They go on to estimate the marginal willingness to pay for physical working conditions ${ }^{7}$. This approach allows for estimation of a structural parameter in absence of a full structural model.

Finally, there is a large literature in management sciences on the factors influencing voluntary turnover which is not reviewed here ${ }^{8}$.

\subsection{Wealth in job search}

In a job search model including capital accumulation, Algan et al. (2003) show that workers' optimal labour market strategy consists in accumulating wealth in bad (not well-paid) jobs and quitting in order to focus on job search for a good (well-paid) job. Thus reservation wages will generally be a function of individuals' wealth holdings (see also Lentz and Tranaes (2005), Lise (2013)). However, in these models, job quality is purely monetary. We may be interested in dynamic aspects in a setting where individuals are interested in one aspect of jobs that cannot be saved (non-monetary job quality) whilst another can (earnings). A dynamic analysis in this sense is beyond the scope of this article (appendix (C) highlights the difficulties of this approach).

\footnotetext{
${ }^{6}$ Thus a many-period game with potentially complex dynamics has a simple static solution, this is the insight famously used in Burdett and Mortensen (1998). It is only when more sophisticated considerations such as using offers as bargaining chips are taken into account that more complicated dynamic strategies are generated (see e.g. Postel-Vinay and Robin (2002)).

${ }^{7}$ The working conditions they consider are: exposure to extreme heat, cold, vibrations; whether workers had to engage in frequent crawling, crouching, kneeling or heavy lifting. van Ommeren et al. (2000) estimate the marginal willingness to pay for commuting distance in the Netherlands.

${ }^{8}$ Bloom and van Reenen (2010) review this literature and contrast methods and results to the economics literature on HRM practices. Haywood (2011) considers managers' reactions when workers become less dependent on the material payoffs of their jobs as a result of windfall gains.
} 
Job quality, search and wealth

As a result of the complicated interrelations between savings decisions and other individual economic conditions and preferences, the use of windfall gains, and specifically lottery winnings, as a means of identification are attractive (e.g. Imbens et al. (2001) and Kuhn et al. (2011) use US and Dutch lottery data). In labour economics, several studies have investigated the impact of windfalls on labour supply. The effect of wealth on relaxing credit constraints and individuals' choice of becoming self-employed have been a specific focus (e.g. Lindh and Ohlsson (1996), Taylor (2001)). Since the self-employed have been found to have higher levels of job satisfaction, becoming self-employed may be one of the ways in which individuals use wealth to increase their non-monetary job quality. Using the same dataset and a similar definition of windfall gains ${ }^{9}$, Henley (2004) considers the effect of wealth on the intensive margin of labour supply. This paper shows that wealth influences not just the amount of labour supplied but also the conditions under which workers are willing to work.

\section{A model of labour market responses to windfalls}

The basic assumption of job search models is that workers cannot access the full range of job offers at any point in time. Rather, job offers arrive randomly (we allow workers to influence this stochastic process by increasing their search intensity). In this environment, traditional labour supply curves are replaced by workers' acceptance strategies when confronted with particular offers (our model implies a set of reservation wages). Observing the characteristics of origin and destination jobs of job-to-job movers in various dimensions then allows us to infer the relative importance of different job aspects. This part formalises identification of the marginal willingness to pay for job characteristics and relates the reduced form parameters to a full job search model.

\subsection{A basic model of quality job search}

Workers care about consumption $c$, non-wage job quality $s$ and not exerting too much search effort $e$. We assume that wealth is exogenous, disallowing wealth accumulation, so that all income is consumed (appendix (C) considers relaxing this assumption). We thus have that $c=m=r a+w$, where $m$ is total income, $w$ is

\footnotetext{
${ }^{9}$ This article uses information on windfalls from lottery and gambling winnings, inheritance, accident and life insurance payouts.
} 
Job quality, search and wealth

labour income and $r$ a gives the returns to wealth.

Including endogenous search effort is fairly simple in a framework with onedimensional job quality (see Mortensen (1986)). However, this simplicity does not immediately extend to a labour market in which jobs differ along wages and a nonmonetary dimension ${ }^{10}$. We here allow for endogenous search effort, where effort is linearly additive in the utility function. We can reason that search requires time $t^{s}$ rather than money and that different job characteristics do not influence the utility cost associated with time search. For example, if time is valued at the wage rate and search costs time, this would violate the assumption of additive separability of search effort. However, even in this case, if individuals cannot freely adjust their hours of work, search activities may not substitute for work.

With search effort $e\left(t^{s}\right)$ and utility from working and consuming $\psi(m, s)$ we then have the following instantaneous utility

$$
\begin{aligned}
u(c, s, e) & =\psi(w+r a, s)-e\left(t^{s}\right) \\
u(m, s, e) & =\psi(m, s)-e\left(t^{s}\right) .
\end{aligned}
$$

Workers receive job offers stochastically at Poisson rate $\lambda t^{s}$, influenced by the

\footnotetext{
${ }^{10}$ The reason for this is that we can only give a structural interpretation to functions of reduced form hazard rates if job characteristics influence job leaving only via the instantaneous utility of a job. This is no longer necessarily the case with endogenous search effort, where job leaving may depend also on the particular combination of monetary and non-monetary aspects in a job beyond the instantaneous utility they generate (see van Ommeren et al. (2000)). Consider the case of monetary search costs. Adapting the standard formulation of the reservation wage function with monetary search intensity and on-the-job search to include non-monetary characteristics $s$, write

$$
\begin{aligned}
\rho R\left(w-c\left(t^{s}(w, s)\right), s\right)= & u\left(w-c\left(t^{s}(w, s)\right), s\right) \\
& +\lambda t^{s} \int_{-\infty}^{\infty} \int_{-\infty}^{\infty} \max \left(0, R\left(w^{\prime}, s^{\prime}\right)-R(w, s)\right) d F\left(w^{\prime}, s^{\prime}\right)+\delta(b-R(w, s)),
\end{aligned}
$$
}

where $R$ is the reservation wage, $c\left(t^{s}\right)$ is the cost of search effort $t^{s}$ (increasing the job offer arrival rate) and $b$ is the level of unemployment benefits. The optimal search effort is implicitly defined by

$u_{m}\left(w-c\left(t^{s *}(w, s)\right), s\right) c_{t^{s}}\left(t^{s *}(w, s)\right)=\lambda \int_{-\infty}^{\infty} \int_{-\infty}^{\infty} \max \left(0, R\left(w^{\prime}, s^{\prime}\right)-R(w, s)\right) d F\left(w^{\prime}, s^{\prime}\right)$.

The optimal level of search effort does not necessarily depend on $w$ and $s$ only via $u(w, s)$. For example, taking a linear cost function $c\left(t^{s}\right)=c t^{s}$, the optimal search effort depends on the marginal utility of money, which may be different for jobs with equal levels of utility. One way to overcome this issue would be to posit an additive linear specification of utility (van Ommeren et al. (2000)) but this amounts to a strong restriction on the key relation this article considers, i.e. the relation between working conditions and wages, removing the role that diminishing marginal utility of money may play in increasing demand for non-material job characteristics at higher wealth levels. 
Job quality, search and wealth

level of search effort $t^{s}$. Note that this allows the unemployed to have a higher job offer arrival rate if they display higher search intensity $t^{s}$. Once an offer is received, workers have perfect information about its characteristics ${ }^{11}$. If we make the further simplifying assumption that workers become unemployed at an exogenous poisson rate $\delta$ and then receive constant monetary benefits $b$, and denoting the joint offer distribution of wages and working conditions $F_{w, s}($.$) , the basic value of$ the employed state is

$$
\begin{aligned}
V(w, s)= & \frac{\psi(m, s)-e\left(t^{s}\right)}{1+\rho}+\delta \frac{V\left(b, s_{0}\right)}{1+\rho} \\
& +\frac{\lambda t^{s}}{1+\rho} \int_{\Omega} V\left(w^{\prime}, s^{\prime}\right) d F_{w, s}\left(w^{\prime}, s^{\prime}\right)+\left(1-\delta-\lambda t^{s} \bar{F}(\Omega)\right) \frac{V(w, s)}{1+\rho},
\end{aligned}
$$

where $\bar{F}(.) \equiv 1-F($.$) is the inverse of the joint offer distribution and we call$ the set of accepted job offers $\Omega\left(w^{\prime}, s^{\prime}\right)$, with $\Omega(w, s)=\left\{w^{\prime}, s^{\prime} \mid \psi\left(m\left(w^{\prime}, a\right), s^{\prime}\right)>\right.$ $\psi(m(w, a), s)\}$. Job offers with characteristics $w^{\prime}, s^{\prime}$ are thus accepted if they are associated with higher instantaneous utility. In this set-up, workers' acceptance strategies only depend on the instantaneous utility of their current job: As the job offer arrival rate does not differ across employment and unemployment conditional on search intensity $t^{s}$, workers do not forego any option value by accepting a job offer with higher instantaneous utility: the value of a job does not influence the value of future job offers ${ }^{12}$. Workers will move when the instantaneous utility of a job exceeds the current level (taking into account both wage and non-wage characteristics). The concept of a reservation wage is replaced by the more realistic idea of a reservation wage function $w^{R}(s)$. Furthermore, it can be seen that assets play a rôle in determining $\Omega($.$) and thus w^{R}($.$) . This generalizes the purely monetary$ reservation-wage property of Mortensen (1986) or van den Berg (2001).

To proceed, we need to show that not only job acceptance conditional on search effort but also the optimal level of search intensity depends only on the instantaneous level of utility. Intuitively, if instantaneous utility fully describes the relative attractiveness of one job vis-à-vis other jobs on offer, it determines expected returns to search also (appendix (B) provides a formal proof). With this in mind, job leaving occurs either when workers are made redundant (at rate $\delta$ ) or when they

\footnotetext{
${ }^{11}$ Gielen (2013) shows that "learning about jobs" is not a major determinant of transitions and concludes that imperfect information about job characteristics is not particularly important in explaining transition decisions.

${ }^{12}$ This excludes the cases where workers renegotiate their contracts, or firms match workers' outside offers. In this case not only the instantaneous utility of a job would be of interest, but firms' ability to match future offers (see e.g. Postel-Vinay and Robin (2002)).
} 
Job quality, search and wealth

receive a job offer whose value exceeds the value of their current job offer - with probability $\lambda t^{s}(\psi(a, w, s)) \bar{F}(\psi(a, w, s))$. The overall rate of job quits $\theta($.$) can$ then be given as

$$
\theta(\psi(m, s))=\delta+\lambda t^{s *}(\psi(m, s)) \bar{F}(\psi(m, s)),
$$

varying over different levels of non-monetary characteristics of the current job,

$$
\frac{\partial \theta}{\partial s}=\frac{\partial \psi}{\partial s}\left[\frac{d t^{s *}}{d \psi} \lambda \bar{F}(\psi)+\frac{d \bar{F}(\psi)}{d \psi} \lambda t^{s *}(\psi(m, s))\right]
$$

and over different levels of the current wage, using $m=r a+w$,

$$
\frac{\partial \theta}{\partial w}=\frac{\partial \psi}{\partial m}\left[\frac{d t^{s *}}{d \psi} \lambda \bar{F}(\psi)+\frac{d \bar{F}(\psi)}{d \psi} \lambda t^{s *}(\psi(m, s))\right] .
$$

Putting the two together gives

$$
\frac{\partial \theta / \partial s}{\partial \theta / \partial w}=\frac{\partial \psi / \partial s}{\partial \psi / \partial m}
$$

The left-hand side of (7) is observed, the right-hand side is the marginal rate of substitution between earnings and working conditions, i.e. the marginal willingness to pay for better working conditions $s$. Following Gronberg and Reed (1994) we can thus estimate a structural parameter, the marginal willingness to pay for non-monetary job attributes (MWP), by considering the job exit rates of different jobs.

\subsection{Wealth shocks in quality job search}

We now use our framework to consider how changes in wealth may influence the MWP for non-monetary job characteristics. As assets change, the MWP will change according to

$$
\begin{aligned}
\frac{\partial}{\partial a}\left[\frac{\partial \theta / \partial s}{\partial \theta / \partial w}\right] & =\frac{\partial}{\partial a}\left[\frac{\partial \psi / \partial s}{\partial \psi / \partial m}\right] \\
& =\frac{\psi_{s m} \psi_{m}-\psi_{m m} \psi_{s}}{\left[\psi_{m}\right]^{2}} .
\end{aligned}
$$

Under standard assumptions about the form of the monetary utility function (diminishing marginal utility of income), expression (9) is positive. Consider an additive specification $\psi(m, s)=\psi_{1}(m)+\psi_{2}(s)$ : Then $\psi_{s m}=0$ and as long 
Job quality, search and wealth

as $\psi_{m m}<0$, expression (9) will be positive ${ }^{13}$. The reasoning for this is that the marginal utility of extra income is less important to individuals with a higher level of wealth. Indeed, if "wealthy agents will be choosier" (Gomes et al. (2001)), the MWP should increase after an exogenous change in wealth ${ }^{14}$. We test this prediction and quantify this novel wealth effect.

\section{Data}

The British Household Panel Survey is a sample of around 10,000 persons largely representative of the British population. We use 18 waves (1991-2010). We restrict our sample to individuals observed at least twice and who receive a windfall at least once during the sample period. This leaves us with 10,386 completed job spells from 3,488 workers. Since we do not model differential job leaving to retirement, we restrict the sample to ages 16-50. Indididuals are asked about their labour market spells and earnings, subjective job satisfaction and windfall receipt. The data also include numerous demographic control variables.

\subsection{Job durations and stock-sampling}

Job quitting is key to our identification strategy, thus defining what constitutes a job is important. We exclude within-firm mobility, and focus on individuals moving between firms, since the latter is more likely to be governed by a random process than the former ${ }^{15}$. Where there are several observations of wage and working contisions for one job, we use the most recent observation - relevant, presumably, for the decision to leave the job. Consider the worker depicted in figure (1). She is employed in wave 11 and provides information on her current job satisfaction and wage. By the time of the wave 12 interview she has changed jobs and provides information on working conditions and earnings at her new employer. From September 2001 to January 2002 we assume that job characteristics have not changed, from January 2002 onwards we assume the job is characterised by the same wage and working conditions as reported in wave 12 . We assume working conditions remain constant from the last interview until leaving a job. Thus we cannot use job

\footnotetext{
${ }^{13}$ When might more wealthy individuals show lower marginal willingness to pay for non-monetary job characteristics? This would require $\psi_{s m}<\psi_{m m} \frac{\psi_{s}}{\psi_{m}}$, i.e. that the marginal utility of better working conditions falls very fast as wealth increases. Most utility functions assume strategic complementarity, however, such that the cross-derivative is positive.

${ }^{14}$ Wealthy agents may also be prepared to do more risky jobs - see Danforth (1979). Lise (2013) also discusses a role for wealth if searching for a job is more costly for the rich.

${ }^{15}$ As a robustness check, we used the alternative definition including leaving to a job in the same firm as a form of job quitting. Results were similar.
} 
Job quality, search and wealth

spells of individuals for which we have no corresponding survey information.

This is one reason we are more likely to observe longer spells. For example, in figure (2), the job from April 2002 onwards is observed, whereas the spell from January to April 2002 is not. We condition on job duration at the sampling date to control for the likelihood of observing an observation (for details on implementation, see appendix (D)). Note that this procedure takes into account a second reason for oversampling long spells - they are more likely to exist at the start of the panel (stocksampling).

For reasons to be explained below, we do not consider individuals for whom we only have one observation (see section (5.1)). We have exact spell dates on multiple job spells for each individual (on average from 2.8 jobs). Censoring may be an issue given that for the longest spells we have no end-date, but this concerns very few spells as there is considerable mobility in the British labour market over the period studied. Many more spells are censored as individuals drop out of the panel for unknown reasons. For these we assume random censoring.

\subsection{Non-monetary job characteristisc and job satisfaction}

As a measure for non-monetary job aspects we require something that workers evaluate independently of their wages ${ }^{16}$. We might consider subjective job satisfaction, i.e. answers to the question "How satisfied are you with your job?". However, answers to this question presumably include both job satisfaction with pay as well as job satisfaction with non-monetary aspects of a job. Instead we use "job satisfaction for work in itself" as a measure for workers' appreciation of all non-monetary aspects of a job. This measure is clearly directed at a subjective evaluation of intrinsic characteristics of the workplace whilst at the same time clearly distinct from financial rewards. The presence of other questions relating specifically to satisfaction with financial rewards should reassure us that the dimension of job quality measured here relates exclusively to factors other than remuneration (see table (1)).

Job satisfaction may include an important subjective component. We could

\footnotetext{
${ }^{16}$ Clearly we cannot test the potential independence by testing the correlation between a measure of non-monetary job characteristics and wages: For the reasons discussed in equilibrium job search models with hedonic components (eg. Hwang et al. (1998)), we would suspect a correlation between non-monetary job satisfaction and wages in the absence of any problem in our measure of nonmonetary job aspects.
} 
Job quality, search and wealth

Table 1: Measures of job satisfaction

\begin{tabular}{lclll} 
& Mean & Standard deviation & Min & Max \\
\hline & & & & \\
Job Satisfaction overall & 5.182 & 1.363 & 1 & 7 \\
& & & & \\
\hline Satisfaction with pay & 4.829 & 1.794 & 1 & 7 \\
Satisfaction with job security & 5.315 & 1.552 & 1 & 7 \\
Satisfaction with work in itself & 5.289 & 1.371 & 1 & 7 \\
Satisfaction with working hours & 5.088 & 1.427 & 1 & 7
\end{tabular}

The precise question was: "I'm going to read out a list of various aspects of jobs, and after each one I'd like you to tell me from this card which number best describes how satisfied or dissatisfied you are with that particular aspect of your own present job." The scale (on the card) varies from "1- Not satisfied" over "4-Not Satisfied, not dissatisfied" to "7-Completely Satisfied".

posit that the objective level of working conditions, $s^{*}$ is actually transformed by personal factors $\nu_{i}$, such that $s_{i, t} \equiv f\left(\nu_{i}, s_{i, t}^{*}\right)$. We do not attempt to model this transformation, but we can allow for subjective reporting under one condition: Since we include a cross-sectional dimension we must require that $\nu_{i}$ is uncorrelated with the size of the wealth shocks, job leaving probability and other covariates, i.e. a random effect. As long as this condition is satisfied, we can allow for individual factors to transform the underlying level of working conditions to a subjective report. We can then rephrase our research question as follows: "How does the influence of self-reported working conditions on job choice change over different wealth levels?" We do not require that individuals have the same attitudes towards specific job characteristics - the same work may be viewed as in itself very satisfying by one person and not by another. This constitutes an important advantage of our reduced-form strategy ${ }^{17}$. In order to test whether wealth shocks lead to more importance given to non-monetary factors, we need attitudes to be stable across time however.

\footnotetext{
${ }^{17}$ Equilibrium job search models that allow for firms to set wages need to calculate worker flows as a function of working conditions, thus requiring homogeneity of ordinal preferences, something we do not require here.
} 
Job quality, search and wealth

Figure 1: Example of timeline of survey interviews and events

\begin{tabular}{|c|c|c|}
\hline Sep 2001 & Jan 2002 & Sep 2002 \\
\hline
\end{tabular}

Figure 2: Example of timeline of survey interviews and events

\begin{tabular}{|c|c|c|c|}
\hline Sep 2001 & Jan 2002 & April 2002 & Sep 2002 \\
\hline $\begin{array}{l}\text { survey interview wave } 11 \\
\text { (job sat., wage, no windfall,...) }\end{array}$ & starts new job & starts new job & $\begin{array}{l}\text { survey interview wave } 12 \\
\text { (job sat., wage, windfall,...) }\end{array}$ \\
\hline
\end{tabular}

\subsection{Windfalls}

We focus on windfalls from lottery and gambling winnings, inheritances, life and accident insurance payouts. We assume that conditional on receiving a windfall, the timing and amount of the windfall are random. This ensures that no behavioural changes can be made prior to the windfall and that individuals with large windfalls are representative of the sample overall. We have no information on the exact date of the windfall ${ }^{18}$, and assume windfalls occur at the beginning of the period between interview dates - any other assumption would violate the no-anticipation assumption in some cases. If a worker reports having received a windfall in the preceding period and also reports job mobility, we thus assume that the windfall occured before the decision to change jobs. This is conservative in the following sense: consider the worker in figure (1) receiving a windfall sometime in the year preceding September 2002. Since the exact timing of the windfall is unclear, we do not know whether it occured before or after January 2002 (the time of the job change). We assume that the windfall occured prior to January 2002. If the windfall was in fact received later, this will generate a lagged effect in later waves without violating the assumption of no-anticipation.

Our sample includes all individuals who report windfall earnings at some point in time ${ }^{19}$. Many windfalls are modest (with a median of $£ 100^{20}$ ), especially those

\footnotetext{
${ }^{18}$ This restricts our ability to test the no-anticipation assumption, and prevents us from adopting a timing-of-events framework à la Abbring and van den Berg (2003).

${ }^{19}$ Note that many windfalls originate in betting and lottery playing. This is a much more common practice in the UK than in many other countries, with apparently up to two thirds of the population engaged in gambling and over 57\% playing the lottery (Clark and Apouey (2013)).

${ }^{20}$ All monetary values provided are deflated to their values in 2000.
} 
Job quality, search and wealth

Table 2: Size of windfalls received

\begin{tabular}{llllll} 
& Inherit. & Lottery & Life ins. & Accident ins. & Total \\
\hline $1-1,000$ pounds & 98 & 2255 & 50 & 41 & 2695 \\
$1,000-5,000$ pounds & 158 & 78 & 198 & 148 & 627 \\
$5,000-10,000$ pounds & 79 & 8 & 32 & 23 & 149 \\
$10,000-50,000$ pounds & 115 & 2 & 42 & 11 & 183 \\
50,000+ pounds & 35 & 1 & 5 & 1 & 49 \\
Note: For one year (wave 5) only aggregated data are available - included in total.
\end{tabular}

Table 3: Size of windfalls as fraction of annual earnings

\begin{tabular}{llllll} 
& Inherit. & Lottery & Life ins. & Accident ins. & Total \\
\hline 1-10 percent & 141 & 2264 & 78 & 61 & 2,788 \\
$10-50$ percent & 153 & 69 & 184 & 122 & 578 \\
50-100 percent & 67 & 8 & 29 & 29 & 139 \\
$100+$ percent & 124 & 3 & 36 & 12 & 198
\end{tabular}

Note: For one year (wave 5) only aggregated data are available - included in total.

from lottery and gambling. By contrast, accident insurance $(£ 237)$ and life insurance $(£ 584)$ but especially inheritances $(£ 2,294)$ are on average more substantial, as table (2) shows. Indeed, a non-negligible fraction of windfalls exceeds annual earnings, as table (3) indicates. 
Job quality, search and wealth

Table 4: Transitions

\begin{tabular}{lll} 
& number of spells & percent \\
\hline to new job & 1,985 & 16.47 \\
to unemployment & 1,107 & 9.19 \\
to university & 83 & 0.69 \\
retirement & 24 & 0.20 \\
family-related & 229 & 1.90 \\
health-related & 170 & 1.41 \\
other & 1,512 & 12.55 \\
censored & 6,940 & 57.59 \\
\hline total & 12,050 & 100
\end{tabular}

\subsection{Wealth shocks and transitions}

Many transitions between labour market states may be affected by changing levels of wealth, including transitions to unemployment, retirement or other nonparticipation. In line with our model, we focus on job-to-job transitions ${ }^{21}$. Involuntary quits (redundancy, sacking, or "family reasons") are by contrast not included in our measure of quits. Due to sample size considerations, we cannot simply include all different reasons for quitting in a competing risks framework.

Descriptive evidence of the impact of wealth shocks on transition behaviour is presented in figure (3) which gives the smoothed hazard rate by receipt of a large windfall (defined as a windfall greater than £2,000) and by job satisfaction (high job satisfaction defined as "nearly completely" or "completely satisfied" workers), focusing on the first 100 months of a job. Quit rates are highest for the group of windfall recipients with low levels of job satisfaction and lowest (over most of the job duration) for windfall recipients with high job satisfaction. This suggests that labour supply effects of wealth may depend importantly on non-monetary characteristics (see section (3.2)).

This variation in the impact of wealth shocks on mobility decisions over different levels of job satisfaction provides a starting point for a more rigorous causal

\footnotetext{
${ }^{21}$ In line with human capital literature, we include "exit to studies". First, taking up studies may be a step in order to find a more satisfying job. Second, it represents a risky choice (as returns to studying are uncertain) - and higher levels of wealth may reduce the degree of risk aversion, increasing the likelihood of making this transition after a windfall. If the reasons for quitting are unclear, we include the observation as potentially affected by wealth effects.
} 
Job quality, search and wealth

Figure 3: Moving to another job: by Windfall and Job Satisfaction Large windfall here defined as windfall greater than $£ 2000$

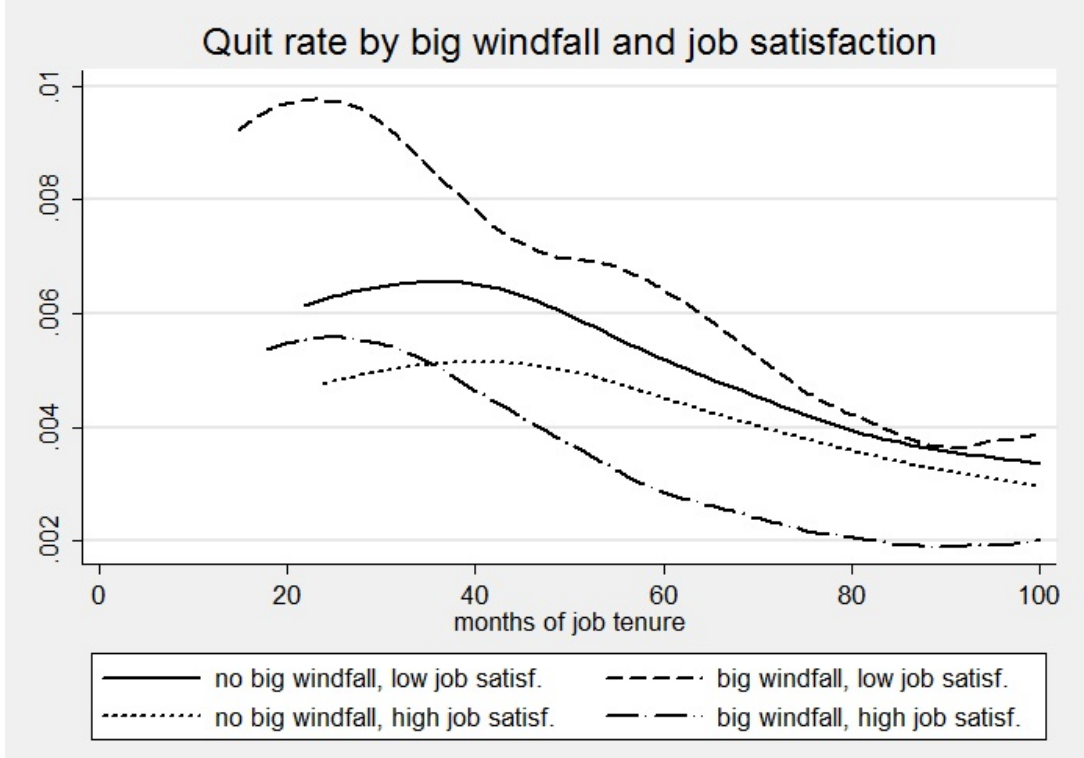

analysis of the question: Do changes in wealth influence the demand for more satisfying jobs?

\section{Estimation}

Following our model, we are interested in the differential effect of windfalls on the job leaving rate, in particular, by wage and job satisfaction. Section (3.1) outlined the reasons for the stationarity of the optimal search strategy: workers compare current job characteristics with job characteristics of job offers arriving at a Poisson rate. This implies an exponential distribution of completed durations in a particular firm, i.e. job characteristics determine the hazard rate of job leaving at every level of wealth. This section investigates the impact of exogenous changes in wealth on this hazard using panel data on windfalls, job durations, wages and working conditions and estimates marginal willingness to pay for non-monetary characteristics following equation (9).

We present two estimation methods which differ in how they treat duration dependence and unobserved individual heterogeneity. Using a mixed proportional 
Job quality, search and wealth

hazard (MPH) specification, unobservables, duration dependency and covariates $x$ (individual characteristics - age, education, marital situation - as well as workspecific characteristics - part-time work, industry dummies etc.) enter multiplicatively in the hazard ${ }^{22}$. To avoid negative hazards, covariates are typically exponentiated in the hazard rate. For job spell $j \in\{1, \ldots, J\}$ of individual $i$ we then have

$$
\theta_{j}=\exp \left(\underline{x_{j}} \underline{\beta}+\eta_{i(j)}\right)
$$

where $\underline{x}_{j} \underline{\beta}=\beta_{w} w_{j}+\beta_{s} s_{j}+\underline{x}_{0 j} \underline{\beta}_{3}$. Our focus is on the change in the coefficients $\beta_{w}$ and $\beta_{s}$ as a result of the wealth shock.

Conditional on the random effect, the density of duration of spell $j$ for individual $i(j)$ follows a negative exponential distribution with parameter $\theta_{j}$, where we focus on individuals who experience at least two spells, so that $J \geq 2$ :

$$
f_{j}\left(t_{j}, \underline{x}_{j} \mid \underline{\beta}, \eta\right)=\exp \left(\underline{x}_{j} \underline{\beta}+\eta_{i(j)}\right) \exp \left(-t_{j} \exp \left(\underline{x}_{i(j), j} \underline{\beta}+\eta_{i(j)}\right)\right)
$$

Our estimation strategies part from this basic model by allowing for more flexibility in unobserved heterogeneity and duration dependence ${ }^{23}$.

\subsection{Heterogeneity}

Unobserved differences across individuals are a particular issue in duration models since they create apparent duration dependency: the most frail individuals have a higher quit rate and thus on average shorter duration $t$, generating a decreasing hazard rate over duration (see van den Berg (2001)). In our MPH specification, we try to minimise the risk of misspecification due to individual heterogeneity:

First, in the Cox Partial Likelihood model (outlined below) we allow for gammadistributed individual effects. Abbring and van den Berg (2007) show that unobserved heterogeneity satisfying the MPH assumption converges relatively fast to a Gamma distribution in the survivor population, providing a justification for this functional form.

\footnotetext{
${ }^{22}$ This very common assumption may rightly appear restrictive - in particular, it implies that only current values of the covariates $\underline{x}$ influence the hazard rate. However, firstly, this is a necessary assumption in order for us to interpret the estimated coefficients of our reduced-form regressions as marginal willingness to pay. Secondly, an Accelerated Failure Time (AFT) specification was estimated, focusing not on the hazard rate but on completed duration as the dependent variable, with similar estimated parameter values.

${ }^{23}$ Results for this basic exponential model (integrating out the unobserved heterogeneity term in equation (11) as in expression (15)) are not presented here, but are similar.
} 
Job quality, search and wealth

Second, since random effects models may nevertheless be sensitive to parametric restrictions, we estimate a second model allowing for a multinomial discrete distribution of heterogeneity following Heckman and Singer (1984).

Third, we restrict our sample to individuals for which we have at least two spells of employment. The potential for misspecification is much less severe in the case of multiple spell data (see van den Berg (2001)).

Fourth, we focus only on individuals who at some time in the sample receive a wealth shock. This should ensure consistent results even if the population of individuals unexpectedly winning the lottery or inheriting wealth is different from those who do not play the lottery and do not inherit. This implies a "treatment of the treated" framework in which unobserved heterogeneity is unlikely to be driving the labour market reactions to wealth shocks.

\subsection{Cox Partial Likelihood}

The Cox Partial Likelihood model (CPL) allows for a flexible form of duration dependence - in fact any multiplicative time-dependent baseline hazard rate is acceptable. The procedure is semi-parametric in the sense that the baseline (unobserved) hazard $\left(\theta_{0}\right.$ in (12)) is not estimated and the partial likelihood estimates of the coefficients $(\underline{\beta})$ are nonetheless consistent. The hazard rate is given as

$$
\theta_{j}\left(t_{j} \mid \underline{x}_{j}\right)=\theta_{0}\left(t_{j}\right) \exp \left(\underline{x}_{j} \underline{\beta}+\eta_{i(j)}\right),
$$

or, defining $\xi_{i} \equiv \exp \left(\eta_{i}\right)$,

$$
\theta_{j}\left(t_{j} \mid \underline{x}_{j}\right)=\theta_{0}\left(t_{j}\right) \theta_{1}\left(\underline{x}_{j}\right) \xi_{i(j)}
$$

where $\theta_{1}($.$) is usually termed the "structural" part of the hazard and \theta_{0}(t)$ the "baseline" hazard. The intuition for the partial likelihood is to use the conditional

probability that job spell $j$ ends, given risk set $R^{j}$ defined as the set of spells ending at or after $j$. Due to the proportionality assumption, the baseline hazard drops out. We thus write the partial likelihood conditional on the individual effects as

$$
L_{i}^{P L}\left(\underline{\beta} \mid t_{j=1 \ldots J}, \underline{x}_{j=1 \ldots J}\right)=\prod_{j=1}^{j=J} \frac{\theta_{1}\left(\underline{x}_{j}\right) \xi_{i(j)}}{\sum_{r \in R^{j}} \theta_{1}\left(\underline{x}_{r}\right) \xi_{i(r)}} .
$$

The CPL model buys semiparametric identification at the cost of efficiency: Only the ordering of job durations influences the likelihood, not the precise timing 
Job quality, search and wealth

( $t$ does not heature in the likelihood given by expression (14)) - so not all information is used for estimation.

For $\xi$ we here follow a parametric route and assume $\xi \stackrel{D}{\rightarrow}$ Gamma. As mentioned, multiple observations per individual are used. In this "shared frailty" framework we then integrate out individual effects for every individual over the product of conditional likelihood contributions,

$$
L_{i}\left(\underline{\beta} \mid t_{j=1 \ldots J(i)}, \underline{x}_{j=1 \ldots J(i)}\right)=\int_{-\infty}^{\infty} \prod_{j=1}^{j=J(i)} f_{j}\left(t_{j}, \underline{x}_{j} \mid r_{i}\right) d G_{\xi}(r)
$$

with $f_{j}\left(t_{j}, \underline{x}_{j}\right)$ defined as in (11).

\subsection{Multinomial random effects / Heckman-Singer}

Whilst the non-parametric baseline hazard of the CPL model allows for unspecified duration dependence, this section focuses on a flexible specification of unobserved heterogeneity. Heckman and Singer (1984) present a non-parametric strategy for introducing unobserved heterogneity in duration models ${ }^{24}$.

This model can be interpreted as assuming that different groups of individuals in the population have discretely different levels of the unobserved heterogeneityterm $\eta$ in equation (10). The appropriate distribution $G_{\xi}($.$) is then multinomial$ discrete across individuals $i$, where $\xi$ is unchanging across spells $j \in\{1, \ldots, J(i)\}$. For $K$ different groups we can then rewrite the individual likelihood-contribution as the expectation of an individual belonging to different groups $k \in\{1, \ldots, K\}$. The individual likelihood-contribution for $i$ is written as:

$$
L_{i}\left(\underline{\beta} \mid t_{j=1 \ldots J(i)}, \underline{x}_{j=1 \ldots J(i)}\right)=\sum_{k=1}^{k=K} p_{k} \prod_{j=1}^{j=J(i)} f_{j}\left(t_{j}, \underline{x}_{j} \mid \eta_{k}\right)
$$

We also want to take into account the fact that - even controlling for heterogeneity - hazard rates appear to decline over time. For the Heckman-Singer model we use a piece-wise linear specification for duration dependence, i.e. we model the function $\theta_{0}(t)$ as a step function ${ }^{25}$. This semi-parametric form implies that $\theta_{0}$ is

\footnotetext{
${ }^{24}$ The method is actually semiparametric since inference is subject to a fixed number of groups. The common estimation procedure - followed here - is to augment the number of groups until the value of the likelihood function does not significantly increase any longer.

${ }^{25}$ Recall that in the CPL model, duration dependence may take any non-parametric form independent of $x$ (any form that respects the proportional hazard condition).
} 
Job quality, search and wealth

constant over discrete periods of time - for estimation we use the following intervals: (i) less than one year; (ii) one to two years; (iii) two to four years; (iv) four to eight years; (v) eight years or more ${ }^{26}$.

\section{Results}

This section presents the main findings and reviews their economic interpretation. Complete results are relegated to tables (5),(6) and (7) in appendix (A). The results indicate, first, that in line with the initial hypothesis, the impact of windfalls on quitting is significantly less important for highly satisfied workers, i.e. that the interaction effect is negative ${ }^{27}$. Second, the wealth effect on demand for good jobs appears to depend importantly on the size of the windfall. In table (5) the effect is shown using a non-linear parametric windfall function. As an alternative to this polynomial specification, we also used a piece-wise linear specification of windfalls (see table (6)). Sample sizes for these categories are not large, thus the groupings are relatively broad to allow reliable estimates even in the highest windfall category (for windfalls above $£ 15,000$ ). Unsurprisingly, relatively small windfalls of up to $£ 5,000$ are found to have no significant impact on labour market behaviour. By contrast, the labour supply of relatively large windfalls does depend on the non-monetary characteristics of jobs.

Third, behavioural reactions to windfalls depend not on their absolute amount but on their amount relative to income. Table (7) shows that if windfalls are expressed as a percentage of annual income, only windfalls of over 50 percent of annual income lead to differential appreciation of the importance of non-monetary job characteristics vis-à-vis wages ${ }^{28}$.

\footnotetext{
${ }^{26}$ These correspond approximately to the quintiles of the survival distribution.

${ }^{27} \mathrm{Ai}$ and Norton (2003) note that the cross-derivative we are interested in is not equal to the interaction effect in non-linear models. The interaction effect will vary over the values of the covariates in a non-linear model. We thus present estimates of the marginal effect as well as estimates of the marginal willingness to pay estimates using the delta method.

${ }^{28}$ In table (7) we see a significant change both in the coefficient on wages and job satisfaction, contrary to the previous two specifications: In neither the non-linear parametric (table (5)) nor the piecewise linear formulation (table (6)) of the windfall effect do we find a significant impact of windfalls on the way in which wages relate to job leaving: wages remain as important after a large windfall as they do before. However, since the relative importance of wages has decreased, the marginal willingness to pay for a satisfying job has increased.
} 
Job quality, search and wealth

\subsection{Marginal willingness to pay}

The increasing marginal effect of job satisfaction on job leaving suggests that the marginal willingness to pay for job quality increases after a windfall. Using the basic formulation (7) we compare estimates of marginal willingness to pay (MWP) before and after windfall gains. From (7) and noting that estimated coefficients refer to the log wage we have

$$
M W P=\frac{\tilde{\beta}_{s}}{\tilde{\beta}_{w}} w .
$$

Concentrating first on the point estimates, we find a five-fold increase in the marginal willingness to pay for one unit of job satisfaction (the standard deviation is 1.37 ) - from around $£ 2,000$ to over $£ 10,000$ for windfalls valued at over $£ 100,000$. In order to illustrate the impact of a windfall we sketch the implied marginal willingness to pay over a range of windfall values (based on simulations using the estimated coefficients and median values for the covariates). Figure (5) shows MWP as a function of windfalls expressed as a fraction of earnings.

The precision of the estimates (standard errors are calculated using the delta method) suggests some caution in the interpretation of the results however. We find that despite large increases in the point estimates, using the specification of windfalls as a percentage of earnings, changes in the marginal willingness to pay are not significant at the 5\% level. Despite the large original sample, the number of individuals affected by large windfalls remains small and limits inference.

\section{Job-to-job transition evidence}

The previous section considered individuals' job satisfaction in their current job and argued that windfalls have an impact on the relative importance of monetary and non-monetary job characteristics in explaining job quitting. For some individuals moving between jobs we observe levels of job satisfaction and wages before and after windfall receipt. Due to the more demanding data requirements, this section is essentially descriptive ${ }^{29}$. We compare the unconditional evolution of job

\footnotetext{
${ }^{29}$ Since we do not know the exact time the windfall was received, we would ideally use observations from three years for every individual - one prior to the year in which a windfall is observed and one from the year after the windfall where it is sure that the windfall has occured (omitting the year in which the windfall occurs). This would leave us with too few observations. Our assumption that the shock occured at the beginning of the year allows us to focus on individuals for whom we have information from two waves. Results should then be a lower bound on the true effects.
} 
Job quality, search and wealth

Figure 4:

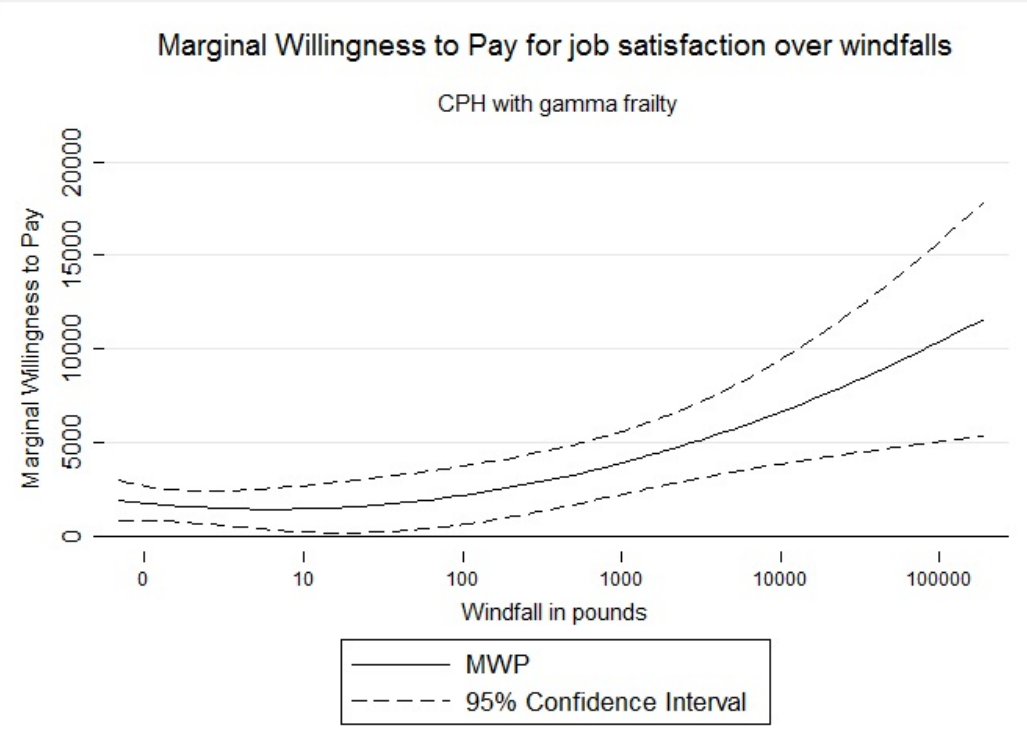

Figure 5:

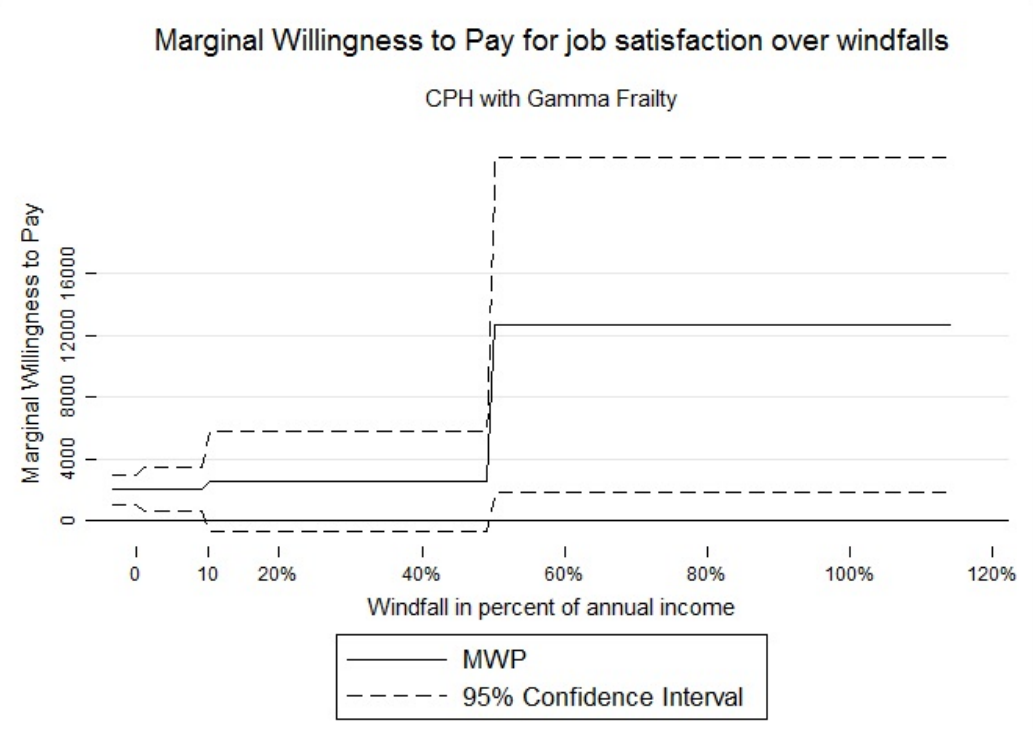


Job quality, search and wealth

satisfaction and wage earnings of 66 persons who received a windfall of at least $£ 1,000$ but did not move jobs, 1,046 persons who moved jobs but did not receive any windfall and 178 individuals who received a windfall of at least $£ 1,000$ and subsequently moved jobs.

If indeed the impact of windfalls on job leaving rates is moderated importantly by job satisfaction, we should expect job satisfaction to increase more for those individuals who change jobs after a wealth windfall than for people moving jobs without having received a windfall. We want to compare movers who received windfall gains with those who did not since moving to a new job is generally associated with important wage gains. However, windfalls also enable dissatisfied workers to move jobs and thus - amongst those who received a windfall - we may also want to compare movers to non-movers. We thus present the evolution of job satisfaction (figure (6)) and of wages - with and without discounting for the average wage growth of a period (figures (7) and (8)).

Selection processes are working on all of the samples: For example, if we take a long period - say 3 years after the windfall shock - and attempt to compare those who stayed in their job and did not change jobs to those who changed jobs, it is certain that the group of non-changers includes many whose working conditions happened to improve over time - independent of the windfall. Thus we focus on the shortest possible time period in which individuals may have the opportunity of moving jobs (i.e. in the next observed wave). Since the exact timing of the windfall receipt is unknown, we use a two-year window between observations.

Figure (6) shows that job satisfaction for work per se increased on average for job changes occuring after windfall receipt (right panel) whilst they remain stable for individuals not moving (left panel) ${ }^{30}$ and, surprisingly, for those moving without having received a windfall (central panel). However, as a result of small sample size, the bands for standard errors imply none of these changes are significant over the two-year window analysed.

Similarly, figures (7) and (8) give the evolution of log (hourly) wages for individuals who receive a windfall and do not move (left panel), individuals who move jobs without having received a windfall (central panel) and individuals who move after receiving a windfall. The most obvious finding is that people are moving

\footnotetext{
${ }^{30}$ So far we had assumed that working conditions throughout a workers' career at a firm are stable - this is not always the case of course when multiple data points for an individual in the same job are available. However, the right panel of figure (6) finds reassuringly little variation over time in the same job.
} 
Job quality, search and wealth

Figure 6: Evolution of job satisfaction for three types of transition

"Job change" observations concern workers who quit and are observed in a new job
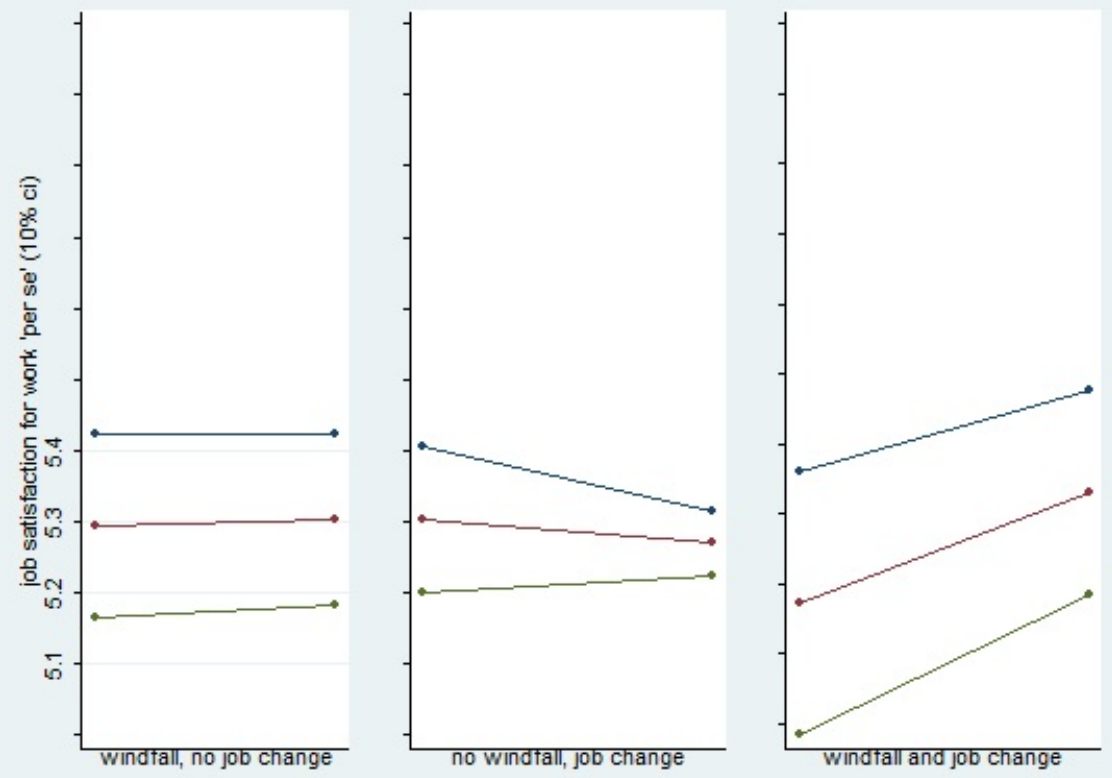
Job quality, search and wealth

Figure 7: Evolution of hourly wage for three types of transition "Job change" observations concern workers who quit and are observed in a new job
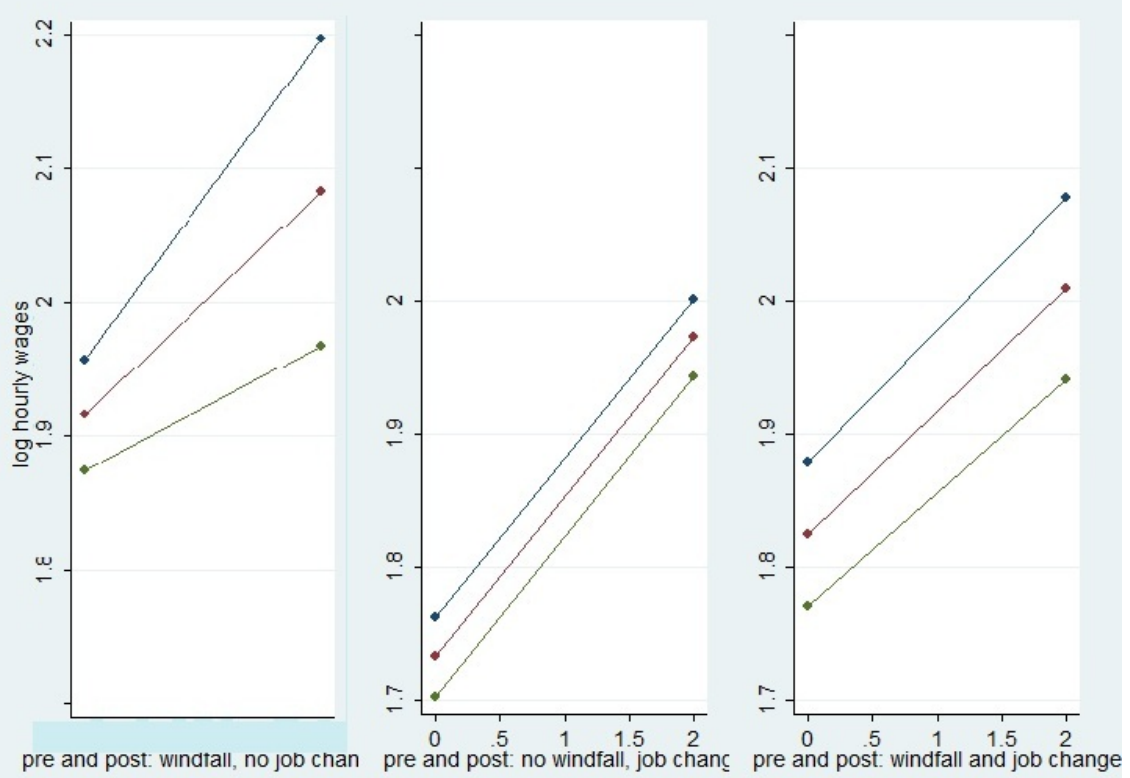

pre and post. windtall, no job chan pre and post. no windfall, job chanç pre and post. windfall and job change 
Job quality, search and wealth

Figure 8: Evolution of hourly wage for three types of transition controlling for wage growth "Job change" observations concern workers who quit and are observed in a new job
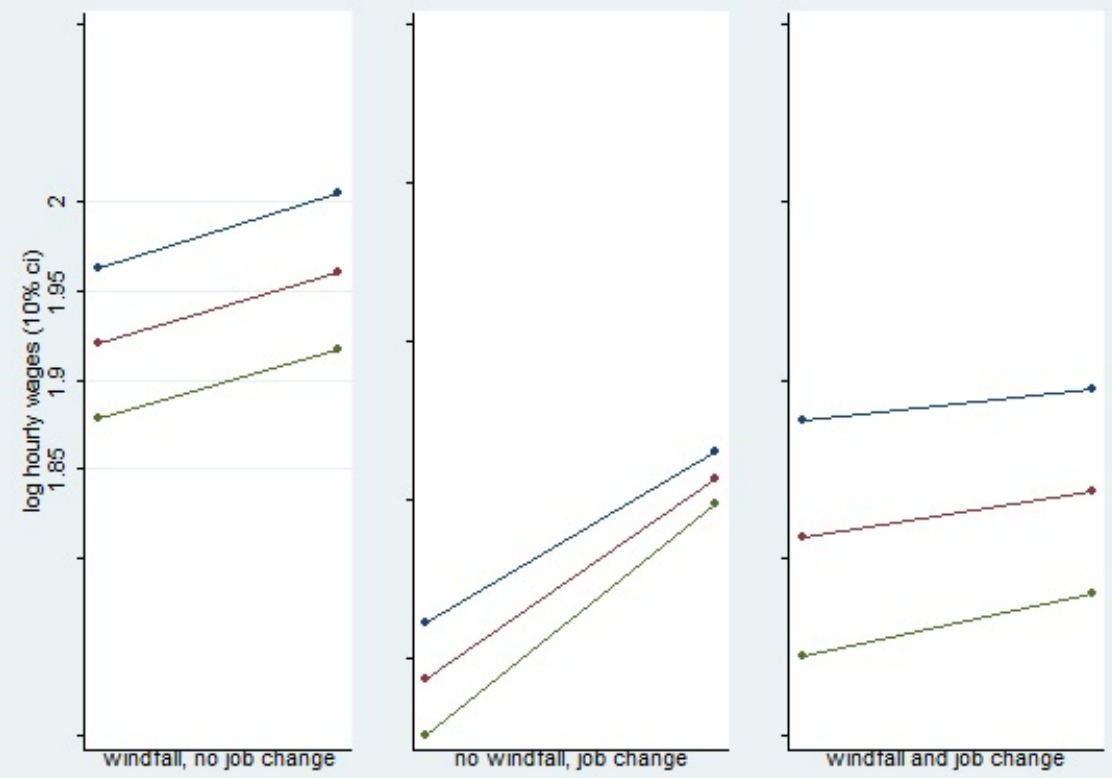
Job quality, search and wealth

away from badly paid jobs: On a common scale the mean wage is significantly lower for movers - independent of windfall receipt. Furthermore, in figure (7) we find that wage growth over the period is most significant for movers who do not receive windfall gains (central panel). Given that we are comparing transitions which occured at different points in (calendar) time with different underlying productivity growth patterns, we correct for this by discounting average wage growth in the whole sample population observed between the particular points in time of any one transition ${ }^{31}$. Figure (8) is thus more easy to interpret: We find that only movers who did not receive a windfall (central panel) receive a significant increase in wages over and above average wage growth: mean log earnings increase only little (and insignificantly) for the movers who received a windfall - potentially indicating that their move was less motivated by earnings than the transitions of the other movers. Workers who received a windfall and did not move had higher earnings - potentially indicating that workers with good promotion prospects decided not to move despite the windfall gains.

Whilst the data do not allow for more elaborate analyses based only on job-tojob transitions, the evidence on transitions is consistent with the idea that workers whose wealth suddenly increases may be particularly sensitive to non-monetary factors when choosing jobs ${ }^{32}$.

\section{Conclusion}

This paper has focused on the impact of wealth in a two-dimensional labour market characterised by frictions, where jobs contain a non-monetary dimension next to the wage. Using British panel data, this paper finds that the demand for good non-monetary characteristics in jobs increases with wealth. The way in which the labour market distributes utility may depend importantly not only on human capital and luck (as in models of the labour market focusing on productivity and frictions) but also on wealth. Wealth is used to quit qualitatively bad jobs and accept qualitatively good jobs that may be less well paid. The basic finding should be relevant to a number of researchers interested in the interactions between inequality, unearned income and subjective wellbeing in the labour market.

\footnotetext{
${ }^{31}$ The samples not only differ by calendar time but also by age, tenure and experience - in fact, only by these three dimensions, since our sample only consists of individuals with windfalls.

${ }^{32}$ Haywood (2011) shows that managers may react to changed demands by changing levels of two specific human ressource responses - flexible working hours and employer pension contributions. That paper uses no theoretical framework and does not calculate MWP for these changes however.
} 
Job quality, search and wealth

Considering different wealth shocks, we find that large windfalls generate significant changes in marginal willingness to pay (MWP). Before receiving a windfall, individuals were willing to forego annual earnings of $£ 2,000$ for a one-point increase in job satisfaction - after receipt of a large windfall this figure increase fivefold. Whilst the resulting estimate of MWP $(£ 10,000)$ is somewhat imprecisely estimated, it represents a marginal propensity to consume job satisfaction out of the windfall gain of around $10 \%$, which does not appear excessive. Behavioural reactions to the increased importance given to non-monetary job characteristics were found to be particularly significant when large windfalls were defined in relation to earnings. The effects found here may only be temporary - but in a frictional labour market, job moves may lead to persistent changes in flows of earnings and job satisfaction.

Fully exploiting the panel dimension of the data, we additionally considered job characteristics (levels of earnings and job satisfaction) in the destination job of job-to-job movers who received a windfall and contrasted them to job characteristics of movers who received no windfall. This provided further suggestive evidence that earnings increase less and job satisfaction increases more for individuals who decide to move jobs after receiving a windfall gain.

The key difficulty in any more general analysis of wealth in a two-dimensional labour market was highlighted in appendix (C). Allowing workers to save a fraction of their income complicates the basic prediction of the job search model. In a dynamic context with savings, the importance of workers' expectations over the joint distribution of wages and working conditions, as well as firms' knowledge of workers' assets has been stressed. In general, it will clearly be in firms' interest to discriminate by asset-holdings of workers. One advantage of the reduced-form strategy presented here is that we can avoid assuming that non-monetary characteristics are valued equally by all or that the valuation is common knowledge (as equilibrium job search models typically would), whilst nevertheless estimating a structural parameter of interest. 
Job quality, search and wealth

\section{A Key result tables}

Table 5: Determinants of job mobility with loglinear windfall function. Dependent variable: hazard rate of job leaving (see table footnote for controls)

\begin{tabular}{|c|c|c|}
\hline & $\begin{array}{l}\text { Cox PH } \\
\hat{\beta} \text { (s.e) }\end{array}$ & $\begin{array}{l}\text { Heckman Singer } \\
\hat{\beta} \text { (s.e.) }\end{array}$ \\
\hline Log Wage (LW) & $\begin{array}{l}-0.484 * * * \\
(0.055)\end{array}$ & $\begin{array}{l}-0.580 * * * \\
(0.581)\end{array}$ \\
\hline Job Satisfaction (JS) & $\begin{array}{l}-0.082 * * * \\
(0.015)\end{array}$ & $\begin{array}{l}-0.082 * * * \\
(0.018)\end{array}$ \\
\hline Log Windfall (LWF) & $\begin{array}{l}-0.242 \\
(0.321)\end{array}$ & $\begin{array}{l}-0.200 \\
(0.365)\end{array}$ \\
\hline LWF squared $\left(\mathrm{LWF}^{2}\right)$ & $\begin{array}{l}0.042 \\
(0.039)\end{array}$ & $\begin{array}{l}0.038 \\
(0.045)\end{array}$ \\
\hline LWF*JS & $\begin{array}{l}0.030 * * \\
(0.013)\end{array}$ & $\begin{array}{l}0.019 \\
(0.015)\end{array}$ \\
\hline $\mathrm{LWF}^{2 * J S}$ & $\begin{array}{l}-0.004 * * * \\
(0.001)\end{array}$ & $\begin{array}{l}-0.004 * \\
(0.001)\end{array}$ \\
\hline LWF*LW & $\begin{array}{l}0.009 \\
(0.034)\end{array}$ & $\begin{array}{l}0.010 \\
(0.038)\end{array}$ \\
\hline $\mathrm{LWF}^{2 *} \mathrm{LW}$ & $\begin{array}{l}-0.001 \\
(0.004)\end{array}$ & $\begin{array}{l}-0.001 \\
(0.004)\end{array}$ \\
\hline$p_{1}$ & & 0.66 \\
\hline$p_{2}$ & & 0.33 \\
\hline$\eta_{1}$ & & 1.60 \\
\hline$\eta_{2}$ & & 0 (normalised) \\
\hline
\end{tabular}

Controls: age, age $^{2}$,education,education ${ }^{2}, 13$ industry dummies, 4 family situation dummies, working hours, part-time dummy;

Sample size: $N=3488 ; N * J=10386$

Significance levels: $10 \%(*), 5 \%(* *), 0.1 \%(* * *)$ 
Job quality, search and wealth

Table 6: Determinants of job mobility with piecewise linear windfall function. Dependent variable: hazard rate of job leaving (see table footnote for controls)

\begin{tabular}{|c|c|c|}
\hline & $\begin{array}{l}\text { Cox PH } \\
\hat{\beta}(\text { s.e })\end{array}$ & $\begin{array}{l}\text { Heckman-Singer } \\
\hat{\beta} \text { (s.e) }\end{array}$ \\
\hline Log Wage (LW) & $\begin{array}{l}-0.588 * * * \\
(0.056)\end{array}$ & $\begin{array}{l}-0.572 * * * \\
(0.054)\end{array}$ \\
\hline Job Satisfaction (JS) & $\begin{array}{l}-0.087 * * * \\
(0.015)\end{array}$ & $\begin{array}{l}-0.086^{* * * *} \\
(0.015)\end{array}$ \\
\hline Windfall (WF1) & $\begin{array}{l}0.843 \\
(0.615)\end{array}$ & $\begin{array}{l}0.817 \\
(0.578)\end{array}$ \\
\hline Windfall (WF2) & $\begin{array}{l}-0.177 \\
(0.293)\end{array}$ & $\begin{array}{l}-0.116 \\
(0.289)\end{array}$ \\
\hline Windfall (WF3) & $\begin{array}{l}0.069 * \\
(0.040)\end{array}$ & $\begin{array}{l}0.063 \\
(0.039)\end{array}$ \\
\hline JS*WF1 & $\begin{array}{l}-0.034 \\
(0.023)\end{array}$ & $\begin{array}{l}-0.0329 \\
(0.022)\end{array}$ \\
\hline JS*WF2 & $\begin{array}{l}-0.028 * * \\
(0.013)\end{array}$ & $\begin{array}{l}-0.026^{* *} \\
(0.010)\end{array}$ \\
\hline JS*WF3 & $\begin{array}{l}-0.001 \\
(0.001)\end{array}$ & $\begin{array}{l}-0.002 \\
0.001\end{array}$ \\
\hline LW*WF1 & $\begin{array}{l}-0.057 \\
(0.065)\end{array}$ & $\begin{array}{l}-0.055 \\
(0.061)\end{array}$ \\
\hline $\mathrm{LW}^{*} \mathrm{WF} 2$ & $\begin{array}{l}0.038 \\
(0.030)\end{array}$ & $\begin{array}{l}0.029 \\
(0.030)\end{array}$ \\
\hline LW*WF3 & $\begin{array}{l}-0.006^{*} \\
(0.004)\end{array}$ & $\begin{array}{l}-0.005 \\
(0.004)\end{array}$ \\
\hline$p_{1}$ & & 0.69 \\
\hline$p_{2}$ & & 0.30 \\
\hline$\eta_{1}$ & & 1.63 \\
\hline$\eta_{2}$ & & 0 (normalised) \\
\hline
\end{tabular}

Windfalls: W1: $£ 1-5000(N * J: 3466)$; W2:£5000-15000 $(N * J: 279)$; W3:£15000+ $(N * J$ : 204); Reference category: $£ 0$ Controls: age, age $^{2}$,education,education ${ }^{2}, 13$ industry dummies, 4 family situation dummies, working hours, part-time dummy;

Sample size: $N=3488 ; N * J=10386$

Significance levels: $10 \%(*), 5 \%(* *), 0.1 \%(* * *)$ 
Job quality, search and wealth

Table 7: Job leaving as a function of wage, job satisfaction, windfalls relative to income and controls. Dependent variable: hazard rate of job leaving (see table footnote for controls)

\begin{tabular}{|c|c|c|}
\hline & $\begin{array}{l}\text { Cox PL } \\
\hat{\beta} \text { (s.e) }\end{array}$ & $\begin{array}{l}\text { Heckman Singer } \\
\hat{\beta} \text { (s.e) }\end{array}$ \\
\hline Log Wage (LW) & $\begin{array}{l}-0.585 * * * \\
(0.055)\end{array}$ & $\begin{array}{l}-0.650 * * * \\
(0.050)\end{array}$ \\
\hline Job Satisfaction (JS) & $\begin{array}{l}-0.099 * * * \\
(0.017)\end{array}$ & $\begin{array}{l}-0.098 * * * \\
(0.017)\end{array}$ \\
\hline Windfall 0-10pct (W10pct) & $\begin{array}{l}-0.111 \\
(0.353)\end{array}$ & $\begin{array}{l}-0.178 \\
(0.342)\end{array}$ \\
\hline Windfall 10-50pct (W50pct) & $\begin{array}{l}0.235 \\
(0.261)\end{array}$ & $\begin{array}{l}0.183 \\
(0.249)\end{array}$ \\
\hline Windfall 50+ pct (W50+pct) & $\begin{array}{l}0.293 * \\
(0.153)\end{array}$ & $\begin{array}{l}0.159 \\
(0.146)\end{array}$ \\
\hline JS*W10pct & $\begin{array}{l}0.037 \\
(0.034)\end{array}$ & $\begin{array}{l}0.050 \\
(0.033)\end{array}$ \\
\hline JS*W50pct & $\begin{array}{l}-0.047 \\
(0.059)\end{array}$ & $\begin{array}{l}-0.052 \\
(0.056)\end{array}$ \\
\hline $\mathrm{JS} * \mathrm{~W} 50+\mathrm{pct}$ & $\begin{array}{l}-0.240 * * \\
(0.109)\end{array}$ & $\begin{array}{l}-0.191 * * \\
(0.094)\end{array}$ \\
\hline $\mathrm{LW}^{*} \mathrm{~W} 10 \mathrm{pct}$ & $\begin{array}{l}-0.010 \\
(0.024)\end{array}$ & $\begin{array}{l}0.005 \\
(0.031)\end{array}$ \\
\hline $\mathrm{LW} * \mathrm{~W} 50 \mathrm{pct}$ & $\begin{array}{l}0.041 \\
(0.041)\end{array}$ & $\begin{array}{l}0.047 \\
(0.042)\end{array}$ \\
\hline $\mathrm{LW} * \mathrm{~W} 50+\mathrm{pct}$ & $\begin{array}{l}0.114 * * \\
(0.051)\end{array}$ & $\begin{array}{l}0.127 * * \\
(0.053)\end{array}$ \\
\hline$p_{1}$ & & 0.62 \\
\hline$p_{2}$ & & 0.37 \\
\hline$\eta_{1}$ & & 1.61 \\
\hline$\eta_{2}$ & & 0 (normalised) \\
\hline
\end{tabular}

Windfalls: W10pct: $1-10 \%$ of annual income $(N * J: 2788)$; W10pct: 10-50\% $(N * J: 578)$; W50pct: $50+\%(N * J: 337)$; Reference Category:0\%

Controls: age, age ${ }^{2}$,education,education ${ }^{2}, 13$ industry dummies, 4 family situation dummies, working hours, part-time dummy;

Sample size: $N=3488 ; N * J=10386$

Significance levels: $10 \%(*), 5 \%(* *), 0.1 \%(* * *) \quad 29$ 
Job quality, search and wealth

\section{B Endogenous search effort}

\section{B.1 Value of employment}

We can allow for edogenous search as long as the costs of search are a component of the utility function that is additively separable from the determinants of the value of the current job. In order to give a structural interpretation to our reduced-form results we need to show that in this case the benefits of search depend only on the instantaneous utility of a job.

Start with a basic discounted value of the employed state:

$$
\begin{aligned}
V(w, s)= & \frac{\psi(m, s)-e\left(t^{s}\right)}{1+\rho}+\delta \frac{V\left(b, s_{0}\right)}{1+\rho} \\
& +\frac{\lambda t^{s}}{1+\rho} \int_{\Omega} V\left(w^{\prime}, s^{\prime}\right) d F_{w, s}\left(w^{\prime}, s^{\prime}\right)+\left(1-\delta-\lambda t^{s} \bar{F}(\Omega)\right) \frac{V(w, s)}{1+\rho} \\
\left(\rho+\delta+\lambda t^{s} \bar{F}(\Omega)\right) V(w, s)= & \psi(m, s)-e\left(t^{s}\right)+\delta V\left(b, s_{0}\right)+\lambda t^{s} \int_{\Omega} V\left(w^{\prime}, s^{\prime}\right) d F_{w, s}\left(w^{\prime}, s^{\prime}\right) \\
\left(\rho+\delta+\lambda t^{s} \bar{F}(\Omega)\right) V(w, s)= & \psi(m, s)-e\left(t^{s}\right)+\delta V\left(b, s_{0}\right) \\
& +\lambda t^{s}[\bar{F}(\Omega) V(w, s)]-\lambda t^{s} \int_{\Omega} V^{\prime}\left(w^{\prime}, s^{\prime}\right) \bar{F}\left(w^{\prime}, s^{\prime}\right) d\left(w^{\prime}, s^{\prime}\right) \\
(\rho+\delta) V(w, s)= & \psi(m, s)-e\left(t^{s}\right)+\delta V\left(b, s_{0}\right)+\lambda t^{s} \int_{\Omega} V^{\prime}\left(w^{\prime}, s^{\prime}\right) \bar{F}\left(w^{\prime}, s^{\prime}\right) d\left(w^{\prime}, s^{\prime}\right)
\end{aligned}
$$

Job offers with characteristics $w^{\prime}, s^{\prime}$ are thus accepted if they are associated with higher instantaneous utility, where we call the set of accepted job offers $\Omega\left(w^{\prime}, s^{\prime}\right)$, with $\Omega(w, s)=\left\{w^{\prime}, s^{\prime} \mid \psi\left(m\left(w^{\prime}, a\right), s^{\prime}\right)>\psi(m(w, a), s)\right\}$. The concept of a reservation wage is now replaced by the more realistic idea of a threshold wage function, varying over the value of non-monetary job quality, $w^{*}(s)$.

Employed individuals set their search effort to maximise the value of their employment status. The first-order condition is then

$$
\begin{aligned}
\frac{\partial V(w, s)}{\partial t^{s}} & =0 \\
\Leftrightarrow & \\
e^{\prime}\left(t^{s}\right) & =\lambda \int_{\Omega} V^{\prime}\left(w^{\prime}, s^{\prime}\right) \bar{F}\left(w^{\prime}, s^{\prime}\right) d\left(w^{\prime}, s^{\prime}\right)
\end{aligned}
$$


Job quality, search and wealth

By using the derivative of equation (18) we can see that the expression for the change value of the employment state in terms of $(w, s)$ depends only on their influence on the instantaneous utility of a job

$$
\begin{aligned}
(\rho+\delta) V^{\prime}(w, s) & =\psi^{\prime}(m, s)+\lambda t^{s} V^{\prime}(w, s) \bar{F}(\Omega)-\frac{\partial t^{s}}{\partial w, s}\left[\lambda \int_{\Omega} V^{\prime}\left(w^{\prime}, s^{\prime}\right) \bar{F}\left(w^{\prime}, s^{\prime}\right) d\left(w^{\prime}, s^{\prime}\right)-e^{\prime}\left(t^{s}\right)\right] \\
V^{\prime}(w, s) & =\frac{\psi^{\prime}(m, s)}{\rho+\delta+\lambda t^{s} \bar{F}(\Omega)}
\end{aligned}
$$

where we use the condition for the optimal search effort to move from equation (20) to (21). Inserting the latter in the value of employment (18), we find

$(\rho+\delta) V(w, s)=\psi(m, s)-e\left(t^{s}\right)+\delta V\left(b, s_{0}\right)+\lambda t^{s} \int_{\Omega} \frac{\psi^{\prime}\left(w^{\prime}, s^{\prime}\right) \bar{F}\left(w^{\prime}, s^{\prime}\right)}{\rho+\delta+\lambda \bar{F}\left(w^{\prime}, s^{\prime}\right)} d\left(w^{\prime}, s^{\prime}\right)$.

To fully express the value of employment in terms of instantaneous utility we need to consider the value of the unemployed state.

\section{B.2 Value of unemployment}

Assuming that the unemployed accept all job offers we have

$$
\begin{aligned}
V\left(b, s_{0}\right) & =\frac{\psi\left(b, s_{0}\right)-e\left(t_{0}^{s}\right)}{1+\rho}+\frac{\lambda t_{0}^{s}}{1+\rho} \int_{\Omega_{0}} V\left(w^{\prime}, s^{\prime}\right) d F\left(w^{\prime}, s^{\prime}\right)+\left(1-\lambda t_{0}^{s}\right) \frac{V\left(b, s_{0}\right)}{1+\rho} \\
\left(\rho+\lambda t_{0}^{s}\right) V\left(b, s_{0}\right) & =\psi\left(b, s_{0}\right)-e\left(t_{0}^{s}\right)+\lambda t^{s} \int_{\Omega_{0}} V\left(w^{\prime}, s^{\prime}\right) f\left(w^{\prime}, s^{\prime}\right) d\left(w^{\prime}, s^{\prime}\right) \\
\rho V\left(b, s_{0}\right) & =\psi\left(b, s_{0}\right)-e\left(t_{0}^{s}\right)+\lambda t_{0}^{s} \int_{\Omega_{0}} V^{\prime}\left(w^{\prime}, s^{\prime}\right) \bar{F}\left(w^{\prime}, s^{\prime}\right) d\left(w^{\prime}, s^{\prime}\right)
\end{aligned}
$$

Separating the interval into components $\Omega_{0}$ to $\Omega(w, s)$ and from $\Omega(w, s)$ to $\bar{\Omega}$ we can now insert this back in the value of employment (equation (22)) to obtain

$$
\begin{gathered}
(\rho+\delta) V(w, s)=u(m, s)+\lambda\left[t^{s}+\frac{\delta}{\rho} t_{0}^{s}\right] \int_{\Omega(w, s)} \frac{\psi^{\prime}\left(w^{\prime}, s^{\prime}\right) \bar{F}\left(w^{\prime}, s^{\prime}\right)}{\rho+\delta+\lambda \bar{F}\left(w^{\prime}, s^{\prime}\right)} d\left(w^{\prime}, s^{\prime}\right) \\
+\frac{\delta}{\rho}\left[u_{0}+\lambda t_{0}^{s} \int_{\Omega_{0}}^{\Omega(w, s)} \frac{\psi^{\prime}\left(w^{\prime}, s^{\prime}\right) \bar{F}\left(w^{\prime}, s^{\prime}\right)}{\rho+\delta+\lambda \bar{F}\left(w^{\prime}, s^{\prime}\right)}\right]
\end{gathered}
$$


Job quality, search and wealth

This provides a non-recursive characterisation of the value of employment in terms of instantaneous utility only. This can now be used to express the value of unemployed in a non-recursive way, inserting expression (26) in the term for the value of unemployment, equation (25).

Showing that the value of both the employed and unemployed state depend only on $(w, s)$ by way of their influence on instantaneous utility flows shows that the optimal level of search will also only depend on $(w, s)$ by way of this part of the utility function. We have therefore shown that for both unemployed and employed individuals, endogenous search can be allowed for.

\section{Wealth accumulation and job search}

The basic job search model does not include asset accumulation by workers. The potential for wealth to impact on labour market outcomes has however been noted in the literature (Algan et al. (2003), Lentz and Tranaes (2005)).

Why might asset accumulation matter? For a welfare analysis, the possibility of consumption smoothing should make a considerable difference: faced with stochastic shocks, risk averse agents would like to engage in precautionary savings. With respect to the degree of inequality that the exogenous job offer arrival rates impose on individuals, this may be reduced or reinforced by allowing for asset accumulation.

In a labour market with non-monetary job characteristics, assets will now serve to both smooth utility from consumption and utility from job satisfaction. This suggests an additional motive for saving: being able to choose a higher quality job with lower earnings in the future. Furthermore, more risk averse agents will show different rates of substitution between job quality and wages as they prefer the security that only higher earnings can provide.

Algan et al. (2003) provide an example of a model of job choice and savings dynamics in which job offers consist of high-paid and low-paid jobs and individuals use wealth accumulation to smooth consumption over the stochastic labour market processes. Asset accumulation here leads to cycles of accumulating wealth, quitting to search for better jobs (a higher rate of job offer arrival for unemployed is assumed) and a positive probability of accepting low-paid jobs when assets fall below some threshold. 
Job quality, search and wealth

Expanding the basic model put forward in section (3.1) requires taking an explicitly dynamic perspective as we cannot abstract from the intertemporal factors as we could in the simple model. Following Lise (2013), assume that workers are allowed to determine an additional state variable asset $(a)$. Workers then try to maximise utility $u($.$) via consumption c$ and good working conditions $(s)$

$$
E_{0} \int_{0}^{\infty} e^{-\rho t}\left[u\left(c_{t}, s_{t}\right)-e\left(t_{t}^{s}\right)\right] d t
$$

subject to the budget constraint

$$
d a=[m-c] d t
$$

where $m=r a+w$ for employed persons and $m=r a+b$ for unemployed persons. The stochastic labour market with frictions implies the law of motion of earnings for employed

$$
d w_{1}=d q_{\lambda s} 1\left[W\left(a, j\left(w^{\prime}, s^{\prime}\right)\right) \geq W\left(a, j\left(w^{\prime}, s\right)\right)\right]\left(w^{\prime}-w\right)+(b-w) d_{q \delta}
$$

where $W$ is the value of employment state with job $(w, s)$. Similarly for unemployed workers

$$
d w_{0}=d q_{\lambda s} 1\left(W\left(a, j\left(w^{\prime}, s^{\prime}\right)\right) \geq U(a)\right)\left(w^{\prime}-b\right)
$$

We now write $y(w, s)$ as an index of job values with cdf $F_{y}($.$) . This implies$ the following value functions for the unemployed state

$\rho U(a)=\max _{c, t^{s}}\left(u\left(c, s_{0}\right)-e\left(t^{s}\right)+U_{a}(a)[r a+b-c]+\lambda t^{s} \int_{0}^{\infty} \max \left[W\left(a, y^{\prime}\right)-U(a), 0\right] d F_{y}\left(y^{\prime}\right)\right)$

and the employed state:

$$
\begin{aligned}
\rho W(a, y)=\max _{c, s} & \left(u(c, s)-e\left(t^{s}\right)+W_{a}(a, j)[r a+w-c]\right. \\
& \left.+\lambda s \int \max \left[W\left(a, y^{\prime}\right)-W(a), 0\right] d F_{y}\left(y^{\prime}\right)+\delta[U(a)-W(a, y)]\right)
\end{aligned}
$$

The model cannot easily be solved analytically. Can we show that optimal behaviour in this setting also implies that the job leaving rate will be differentially impacted by differences in wealth holdings - exogenous and/or endogenous? The difficulty lies in the fact that it is no longer an inoccuous choice for an individual to accept a job which has higher instantaneous utility: In order to build up assets, individuals may accept a job with a lower instantaneous utility under certain conditions. As a result, the "reservation utility" that we posited in the simple model 
Job quality, search and wealth

does not, in general, follow through into the world of endogenous savings. There is then no unique ordering of jobs and thus no simple way of characterising labour market equilibrium and endogenising the wage in this setting.

Adding asset accumulation to the canonical on-the-job search model preserves the reservation wage character, and homogeneous ordering of jobs in the economy. Adding non-wage characteristics without asset accumulation generates a new reservation utility but preserves a unique ordering of job values and thus allows us to express labour market flows and endogenous wages. Adding both asset accumulation and non-wage characteristics is much more difficult.

\section{Sampling}

The data in our sample is both left-truncated and subject to a form of stock sampling. The data is left-truncated because no spells ending prior to 1991 are recorded. Thus, amongst the sample surveyed in 1991 only spells surviving until this date are surveyed. For the first wave, we are faced with standard stock sampling: the likelihood of observing a spell monotonously increases with its length. We need to assume that economic conditions prior to the begin of our sample were not different in order to condition on survival until the beginning of our sample.

There is a second sampling issue. Assume an individual's complete labour market history is covered in the sample, i.e. there is no left truncation at the start of the observation period of an individual in the sample. Since information about working conditions and wages is only available for jobs about which individuals are interviewed, the likelihood of spells being included in the likelihood again depends on spell length. However, sampling occurs with certainty for job spells that last 12 months and longer, but with decreasing probability as a function of job spell for shorter spells.

We deal with the two issues by conditioning on survival until the first observation of any spell ${ }^{33}$. In the terminology adopted by the duration data literature, individuals become "at risk" (of leaving their job) when they are first observed in the data for their new spell. For their first spell in the data, this might correspond to several years (as a result of left truncation), for later spells of the same individual, the maximum should be 12 months for a job spell started immediately after the preceding interview.

\footnotetext{
${ }^{33}$ Dynamic selection via individual heterogeneity is not taken into account in this treatment. However, van den Berg and Drepper (2011) show how this can be done.
} 
Job quality, search and wealth

\section{E Complete Tables}

Table 8: Determinants of job mobility with loglinear windfall function. Dependent variable: hazard rate of job leaving (see table footnote for reference categories)

\begin{tabular}{|c|c|c|}
\hline & Cox PL & Heckman Singer \\
\hline Log Wage (LW) & $\begin{array}{l}-0.484 * * * \\
(0.055)\end{array}$ & $\begin{array}{l}-0.580 * * * \\
(0.581)\end{array}$ \\
\hline Job Satisfaction (JS) & $\begin{array}{l}-0.082 * * * \\
(0.015)\end{array}$ & $\begin{array}{l}-0.082 * * * \\
(0.018)\end{array}$ \\
\hline Log Windfall (LWF) & $\begin{array}{l}-0.242 \\
(0.321)\end{array}$ & $\begin{array}{l}-0.200 \\
(0.365)\end{array}$ \\
\hline Log Windfall squared $\left(\mathrm{LWF}^{2}\right)$ & $\begin{array}{l}0.042 \\
(0.039)\end{array}$ & $\begin{array}{l}0.038 \\
(0.045)\end{array}$ \\
\hline Log Windfall \& Job satisfaction (interaction) & $\begin{array}{l}0.030 * * \\
(0.013)\end{array}$ & $\begin{array}{l}0.019 \\
(0.015)\end{array}$ \\
\hline Log Windfall squared \& Job satisfaction (interaction) & $\begin{array}{l}-0.004 * * * \\
(0.001)\end{array}$ & $\begin{array}{l}-0.004 * \\
(0.001)\end{array}$ \\
\hline Log windfall \& Log wage (interaction) & $\begin{array}{l}0.009 \\
(0.034)\end{array}$ & $\begin{array}{l}0.010 \\
(0.038)\end{array}$ \\
\hline Log windfall squared \& log wage (interaction) & $\begin{array}{l}-0.001 \\
(0.004)\end{array}$ & $\begin{array}{l}-0.001 \\
(0.004)\end{array}$ \\
\hline Education & $\begin{array}{l}-0.134 * * * \\
(0.022)\end{array}$ & $\begin{array}{l}-0.097 * * * \\
(0.016)\end{array}$ \\
\hline Education squared & $\begin{array}{l}0.007 * * * \\
(0.001)\end{array}$ & $\begin{array}{l}0.005 * * * \\
(0.000)\end{array}$ \\
\hline Agriculture $^{1}$ & $\begin{array}{l}0.799 * * \\
(0.319)\end{array}$ & $\begin{array}{l}0.856 \text { **** } \\
(0.267)\end{array}$ \\
\hline Mining $^{1}$ & $\begin{array}{l}0.305 \\
(0.451)\end{array}$ & $\begin{array}{l}0.130 \\
(0.395)\end{array}$ \\
\hline Construction $^{1}$ & $\begin{array}{l}0.0311 \\
(0.169)\end{array}$ & $\begin{array}{l}-0.048 \\
(0.146)\end{array}$ \\
\hline Wholesale \& Retail ${ }^{1}$ & $\begin{array}{l}0.399 * * * \\
(0.102)\end{array}$ & $\begin{array}{l}0.328 * * * \\
(0.087)\end{array}$ \\
\hline Hotels \& Restaurant ${ }^{1}$ & $\begin{array}{l}0.766 * * * \\
(0.151)\end{array}$ & $\begin{array}{l}0.631 * * * \\
(0.125)\end{array}$ \\
\hline Transport, Communication, Utilities ${ }^{1}$ & $\begin{array}{l}0.360 * * * \\
(0.127)\end{array}$ & $\begin{array}{l}0.290 * * \\
(0.109)\end{array}$ \\
\hline Finance $^{1}$ & $\begin{array}{l}0.216 \\
(0.144)\end{array}$ & $\begin{array}{l}0.161 \\
(0.124)\end{array}$ \\
\hline Real estate, Renting, R\&D, Consulting ${ }^{1}$ & $\begin{array}{l}0.351 * * * \\
(0.111)\end{array}$ & $\begin{array}{l}0.276 * * \\
(0.097)\end{array}$ \\
\hline Public Administration, Social Work, International Orgs ${ }^{1}$ & $\begin{array}{l}-0.023 \\
(0.126)\end{array}$ & $\begin{array}{l}-0.033 \\
(0.111)\end{array}$ \\
\hline
\end{tabular}

table continued overleaf 
Job quality, search and wealth

\begin{tabular}{|c|c|c|}
\hline & Cox PL & Heckman Singer \\
\hline Education, Teaching $^{1}$ & $\begin{array}{l}-0.174 \\
(0.145)\end{array}$ & $\begin{array}{l}-0.235^{*} \\
(0.129)\end{array}$ \\
\hline Health \& Social Work ${ }^{1}$ & $\begin{array}{l}0.258 * * \\
(0.115)\end{array}$ & $\begin{array}{l}0.187 * \\
(0.099)\end{array}$ \\
\hline Community, Arts \& personal service ${ }^{1}$ & $\begin{array}{l}0.220 \\
(0.159)\end{array}$ & $\begin{array}{l}0.119 \\
(0.138)\end{array}$ \\
\hline Other Industry Sector ${ }^{1}$ & $\begin{array}{l}1.03 * * * \\
(0.080)\end{array}$ & $\begin{array}{l}0.859 * * * \\
(0.068)\end{array}$ \\
\hline Separated from Partner ${ }^{2}$ & $\begin{array}{l}0.648 * * * \\
(0.152)\end{array}$ & $\begin{array}{l}0.395 * * * \\
(0.122)\end{array}$ \\
\hline Divorced $^{2}$ & $\begin{array}{l}0.390 * * * \\
(0.106)\end{array}$ & $\begin{array}{l}0.344 * * * \\
(0.084)\end{array}$ \\
\hline Married $^{2}$ & $\begin{array}{l}0.037 \\
(0.065)\end{array}$ & $\begin{array}{l}0.051 \\
(0.051)\end{array}$ \\
\hline Widowed $^{2}$ & $\begin{array}{l}-0.173 \\
(0.330)\end{array}$ & $\begin{array}{l}0.035 \\
(0.277)\end{array}$ \\
\hline Hours & $\begin{array}{l}0.018 * * * \\
(0.004)\end{array}$ & $\begin{array}{l}0.014 * * * \\
(0.003)\end{array}$ \\
\hline Part-time (dummy) & $\begin{array}{l}0.188^{*} \\
(0.103)\end{array}$ & $\begin{array}{l}0.068 \\
(0.086)\end{array}$ \\
\hline Age (years) & $\begin{array}{l}-0.281 * * * \\
(0.024)\end{array}$ & $\begin{array}{l}-0.136 \\
(0.019)\end{array}$ \\
\hline Age (years squared) & $\begin{array}{l}0.002 * * * \\
(0.000)\end{array}$ & $\begin{array}{l}0.001 \\
(0.000)\end{array}$ \\
\hline Tenure $(<1 \text { year })^{3}$ & & $\begin{array}{l}0.791 * * * \\
(0.085)\end{array}$ \\
\hline Tenure $(1-2 \text { years })^{3}$ & & $\begin{array}{l}0.979 * * * \\
(0.074)\end{array}$ \\
\hline Tenure $(2-4 \text { years })^{3}$ & & $\begin{array}{l}1.230 * * * \\
(0.066)\end{array}$ \\
\hline Tenure $(4-8 \text { years })^{3}$ & & $\begin{array}{l}0.845^{* * * *} \\
(0.067)\end{array}$ \\
\hline Constant & & $\begin{array}{l}0.553 * * * \\
(0.666)\end{array}$ \\
\hline$p_{1}$ & & 0.66 \\
\hline$p_{2}$ & & 0.33 \\
\hline$\eta_{1}$ mass point (normalisation: $\eta_{2}=0$ ) & & 1.60 \\
\hline$\xi$ frailty variance (see equ'n (14)) & $\begin{array}{l}0.820 \\
(0.063)\end{array}$ & \\
\hline $\begin{array}{l}\text { Sample size: } N=3488 ; N * S=1038 \\
\text { Significance levels: } 10 \%(*), 5 \%(* *), 0.1 \% \\
{ }^{1} \text { Reference category is manufacturing in } \\
2 \text { Reference category is single family sta }\end{array}$ & $\begin{array}{l}* *) \\
\text { ustry. }\end{array}$ & \\
\hline
\end{tabular}


Job quality, search and wealth

Table 9: Determinants of job mobility with piecewise linear windfall function. Dependent variable: hazard rate of job leaving (see table footnote for controls)

\begin{tabular}{|c|c|c|}
\hline & Cox PL & Heckman Singer \\
\hline Log Wage (LW) & $\begin{array}{l}-0.588^{* * * *} \\
(0.056)\end{array}$ & $\begin{array}{l}-0.572^{* * * *} \\
(0.054)\end{array}$ \\
\hline Job Satisfaction (JS) & $\begin{array}{l}-0.087 \text { *** } \\
(0.015)\end{array}$ & $\begin{array}{l}-0.086^{* * * *} \\
(0.015)\end{array}$ \\
\hline Windfall (WF1) & $\begin{array}{l}0.843 \\
(0.615)\end{array}$ & $\begin{array}{l}0.817 \\
(0.578)\end{array}$ \\
\hline Windfall (WF2) & $\begin{array}{l}-0.177 \\
(0.293)\end{array}$ & $\begin{array}{l}-0.116 \\
(0.289)\end{array}$ \\
\hline Windfall (WF3) & $\begin{array}{l}0.069 * \\
(0.040)\end{array}$ & $\begin{array}{l}0.063 \\
(0.039)\end{array}$ \\
\hline JS*WF1 & $\begin{array}{l}-0.034 \\
(0.023)\end{array}$ & $\begin{array}{l}-0.0329 \\
(0.022)\end{array}$ \\
\hline JS*WF2 & $\begin{array}{l}-0.028 * * \\
(0.013)\end{array}$ & $\begin{array}{l}-0.026^{* * *} \\
(0.010)\end{array}$ \\
\hline JS*WF3 & $\begin{array}{l}-0.001 \\
(0.001)\end{array}$ & $\begin{array}{l}-0.002 \\
0.001\end{array}$ \\
\hline LW*WF1 & $\begin{array}{l}-0.057 \\
(0.065)\end{array}$ & $\begin{array}{l}-0.055 \\
(0.061)\end{array}$ \\
\hline LW*WF2 & $\begin{array}{l}0.038 \\
(0.030)\end{array}$ & $\begin{array}{l}0.029 \\
(0.030)\end{array}$ \\
\hline LW*WF3 & $\begin{array}{l}-0.006^{*} \\
(0.004)\end{array}$ & $\begin{array}{l}-0.005 \\
(0.004)\end{array}$ \\
\hline Education & $\begin{array}{l}-0.106 \text { *** } \\
(0.021)\end{array}$ & $\begin{array}{l}-0.107 * * * \\
(0.020)\end{array}$ \\
\hline Education squared & $\begin{array}{l}0.006 * * * \\
(0.001)\end{array}$ & $\begin{array}{l}0.006 * * * \\
(0.001)\end{array}$ \\
\hline Agriculture $^{1}$ & $\begin{array}{l}0.822 \\
(0.589)\end{array}$ & $\begin{array}{l}-0.637 * * \\
(0.307)\end{array}$ \\
\hline Mining ${ }^{1}$ & $\begin{array}{l}0.091 \\
(0.503)\end{array}$ & $\begin{array}{l}-0.703 \\
(0.587)\end{array}$ \\
\hline Construction $^{1}$ & $\begin{array}{l}0.115 \\
(0.520)\end{array}$ & $\begin{array}{l}-0.655 \\
(0.330)\end{array}$ \\
\hline Wholesale \& Retail ${ }^{1}$ & $\begin{array}{l}0.523 \\
(0.504)\end{array}$ & $\begin{array}{l}-0.227 \\
(0.307)\end{array}$ \\
\hline Hotels \& Restaurant ${ }^{1}$ & $\begin{array}{l}0.797 \\
(0.515)\end{array}$ & $\begin{array}{l}0.059 \\
(0.327)\end{array}$ \\
\hline Transport, Communication, Utilities ${ }^{1}$ & $\begin{array}{l}0.384 \\
(0.509)\end{array}$ & $\begin{array}{l}0.359 \\
(0.317)\end{array}$ \\
\hline Finance $^{1}$ & $\begin{array}{l}0.336 \\
(0.513)\end{array}$ & $\begin{array}{l}-0.412 \\
(0.322)\end{array}$ \\
\hline Real estate, Renting, R\&D, Consulting ${ }^{1}$ & $\begin{array}{l}0.423 \\
(0.505)\end{array}$ & $\begin{array}{l}-0.310 \\
(0.311)\end{array}$ \\
\hline Public Administration, Social Work, International Orgs ${ }^{1}$ & $\begin{array}{l}-0.002 \\
(0.509)\end{array}$ & $\begin{array}{l}-0.728 \\
(0.317)\end{array}$ \\
\hline Education, Teaching ${ }^{1}$ & $\begin{array}{l}-0.121 \\
(0.515)\end{array}$ & $\begin{array}{l}-0.859 * * \\
(0.327)\end{array}$ \\
\hline Health \& Social Work ${ }^{1}$ & $\begin{array}{l}0.170 \\
(0.518)\end{array}$ & $\begin{array}{l}-0.462 * \\
(0.312)\end{array}$ \\
\hline Community, Arts \& personal service ${ }^{1}$ & $\begin{array}{l}0.120 \\
(0.327)\end{array}$ & $\begin{array}{l}-0.568 \\
(0.329)\end{array}$ \\
\hline Other Industry Sector ${ }^{1}$ & $\begin{array}{l}0.996^{* *} \\
(0.500)\end{array}$ & $\begin{array}{l}0.276 \\
(0.301)\end{array}$ \\
\hline
\end{tabular}


Job quality, search and wealth

\begin{tabular}{|c|c|c|c|}
\hline & Cox PL & Heckman Singer & \\
\hline Separated from Partner ${ }^{2}$ & $\begin{array}{l}0.448^{* * * *} \\
(0.149)\end{array}$ & $\begin{array}{l}0.410^{* *} \\
(0.143)\end{array}$ & \\
\hline Divorced $^{2}$ & $\begin{array}{l}0.407 * * * \\
(0.103)\end{array}$ & $\begin{array}{l}0.358 * * * \\
(0.098)\end{array}$ & \\
\hline Married $^{2}$ & $\begin{array}{l}0.076 \\
(0.063)\end{array}$ & $\begin{array}{l}0.062 \\
(0.061)\end{array}$ & \\
\hline Widowed $^{2}$ & $\begin{array}{l}-0.173 \\
(0.384)\end{array}$ & $\begin{array}{l}-0.044 \\
(0.374)\end{array}$ & \\
\hline Hours & $\begin{array}{l}0.018 * * * \\
(0.003)\end{array}$ & $\begin{array}{l}0.019 * * * \\
(0.003)\end{array}$ & \\
\hline Part-time (dummy) & $\begin{array}{l}0.128 * \\
(0.100)\end{array}$ & $\begin{array}{l}0.143 \\
(0.098)\end{array}$ & \\
\hline Age (years) & $\begin{array}{l}-0.181 * * * \\
(0.023)\end{array}$ & $\begin{array}{l}-0.182 * * * \\
(0.023)\end{array}$ & \\
\hline Age (years squared) & $\begin{array}{l}0.002 * * * \\
(0.000)\end{array}$ & $\begin{array}{l}0.001 * * * \\
(0.000)\end{array}$ & \\
\hline Tenure $(<1 \text { year })^{3}$ & & $\begin{array}{l}-0.395 * * * \\
(0.091)\end{array}$ & \\
\hline Tenure $(1-2 \text { years })^{3}$ & & $\begin{array}{l}0.137 * * * \\
(0.086)\end{array}$ & \\
\hline Tenure $(2-4 \text { years })^{3}$ & & $\begin{array}{l}0.236 * * * \\
(0.083)\end{array}$ & \\
\hline Tenure $(4-8 \text { years })^{3}$ & & $(0.083)$ & 0.105 \\
\hline Constant & & $\begin{array}{l}4.00 * * * \\
(0.6424)\end{array}$ & \\
\hline$p_{1}$ & & 0.690 & \\
\hline$p_{2}$ & & 0.309 & \\
\hline $\begin{array}{l}\eta_{1} \text { mass point (normalisation: } \eta_{2}=0 \text { ) } \\
\xi \text { frailty variance (see equ'n }(14) \text { ) }\end{array}$ & $\begin{array}{l}0.828 \\
(0.063)\end{array}$ & 1.628 & \\
\hline
\end{tabular}

Windfalls: W1: $£ 1-5000(N * S: 3466)$; W2: $£ 5000-15000(N * S: 279)$; W3:£15000+ $(N * S$ :

204); Reference category: $£ 0$

Sample size: $N=3488 ; N * S=10386$

Significance levels: $10 \%(*), 5 \%(* *), 0.1 \%(* * *)$

${ }^{1}$ Reference category is manufacturing industry.

${ }^{2}$ Reference category is single family status.

${ }^{3}$ Reference category is job tenure of more than 8 years. 
Job quality, search and wealth

Table 10: Job leaving as a function of wage, job satisfaction, windfalls relative to income and controls. Dependent variable: hazard rate of job leaving (see table footnote for controls)

\begin{tabular}{|c|c|c|}
\hline & $\begin{array}{l}\text { Cox PL } \\
\hat{\beta} \text { (s.e) }\end{array}$ & $\begin{array}{l}\text { Heckman Singer } \\
\hat{\beta} \text { (s.e.) }\end{array}$ \\
\hline Log Wage (LW) & $\begin{array}{l}-0.585 \text { **** } \\
(0.055)\end{array}$ & $\begin{array}{l}-0.650 * * * \\
(0.050)\end{array}$ \\
\hline Job Satisfaction (JS) & $\begin{array}{l}-0.099 * * * \\
(0.017)\end{array}$ & $\begin{array}{l}-0.098 * * * \\
(0.017)\end{array}$ \\
\hline Windfall 0-10pct (W10pct) & $\begin{array}{l}-0.111 \\
(0.353)\end{array}$ & $\begin{array}{l}-0.178 \\
(0.342)\end{array}$ \\
\hline Windfall 10-50pct (W50pct) & $\begin{array}{l}0.235 \\
(0.261)\end{array}$ & $\begin{array}{l}0.183 \\
(0.249)\end{array}$ \\
\hline Windfall $50+$ pct (W50+pct) & $\begin{array}{l}0.293 * \\
(0.153)\end{array}$ & $\begin{array}{l}0.159 \\
(0.146)\end{array}$ \\
\hline JS*W10pct & $\begin{array}{l}0.037 \\
(0.034)\end{array}$ & $\begin{array}{l}0.050 \\
(0.033)\end{array}$ \\
\hline JS*W50pct & $\begin{array}{l}-0.047 \\
(0.059)\end{array}$ & $\begin{array}{l}-0.052 \\
(0.056)\end{array}$ \\
\hline $\mathrm{JS} * \mathrm{~W} 50+\mathrm{pct}$ & $\begin{array}{l}-0.240 * * \\
(0.109)\end{array}$ & $\begin{array}{l}-0.191 * * \\
(0.094)\end{array}$ \\
\hline LW*W10pct & $\begin{array}{l}-0.010 \\
(0.024)\end{array}$ & $\begin{array}{l}0.005 \\
(0.031)\end{array}$ \\
\hline LW*W50pct & $\begin{array}{l}0.041 \\
(0.041)\end{array}$ & $\begin{array}{l}0.047 \\
(0.042)\end{array}$ \\
\hline $\mathrm{LW} * \mathrm{~W} 50+\mathrm{pct}$ & $\begin{array}{l}0.114 * * \\
(0.051)\end{array}$ & $\begin{array}{l}0.127 * * \\
(0.053)\end{array}$ \\
\hline Education & $\begin{array}{l}-0.107 * * * \\
(0.021)\end{array}$ & \\
\hline Education squared & $\begin{array}{l}0.006 * * * \\
(0.001)\end{array}$ & \\
\hline Agriculture $^{1}$ & $\begin{array}{l}0.857 \\
(0.590)\end{array}$ & \\
\hline Mining ${ }^{1}$ & $\begin{array}{l}0.121 \\
(0.521)\end{array}$ & \\
\hline Construction $^{1}$ & $\begin{array}{l}0.138 \\
(0.520)\end{array}$ & \\
\hline Wholesale \& Retail ${ }^{1}$ & $\begin{array}{l}0.550 \\
(0.505)\end{array}$ & \\
\hline Hotels \& Restaurant ${ }^{1}$ & $\begin{array}{l}0.815 \\
(0.516)\end{array}$ & \\
\hline Transport, Communication, Utilities ${ }^{1}$ & $\begin{array}{l}0.410 \\
(0.510)\end{array}$ & \\
\hline Finance $^{1}$ & $\begin{array}{l}0.358 \\
(0.514)\end{array}$ & \\
\hline Real estate, Renting, R\&D, Consulting ${ }^{1}$ & $\begin{array}{l}0.452 \\
(0.507)\end{array}$ & \\
\hline Public Administration, Social Work, International Orgs ${ }^{1}$ & $\begin{array}{l}-0.023 \\
(0.510)\end{array}$ & \\
\hline Education, Teaching ${ }^{1}$ & $\begin{array}{l}-0.093 \\
(0.516)\end{array}$ & \\
\hline Health \& Social Work ${ }^{1}$ & $\begin{array}{l}0.310 \\
(0.508)\end{array}$ & \\
\hline Community, Arts \& personal service ${ }^{1}$ & $\begin{array}{l}0.198 \\
(0.519)\end{array}$ & \\
\hline Other Industry Sector ${ }^{1}$ & $\begin{array}{l}1.014 * * \\
(0.501)\end{array}$ & \\
\hline
\end{tabular}

table continued overleaf 
Job quality, search and wealth

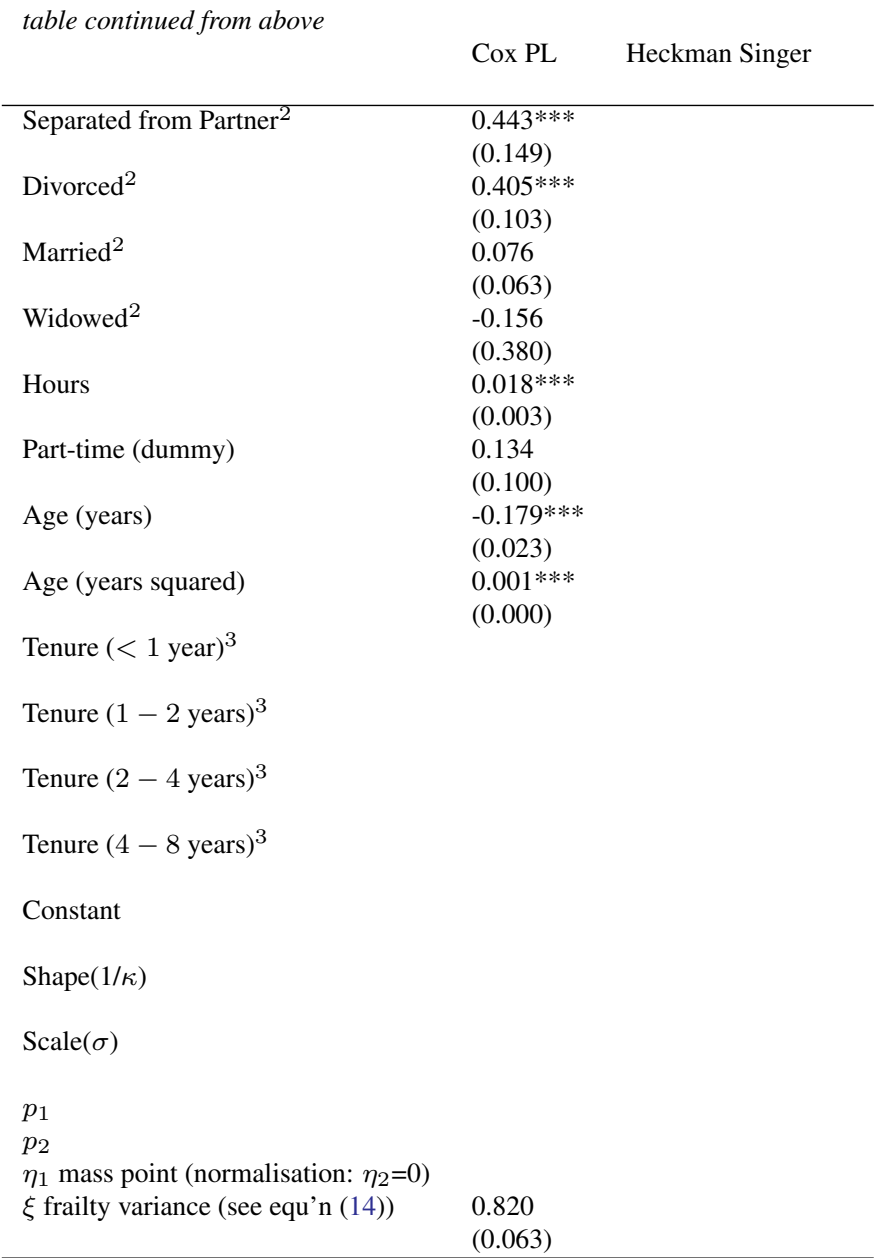

Windfalls: W10pct: 1-10\% of annual income (N*S: 2788); W10pct: 10-50\% (N*S: 578); W50pct: $50+\%(\mathrm{~N} * \mathrm{~S}: 337)$; Reference Category: $0 \%$

${ }^{1}$ Reference category is manufacturing industry.

${ }^{2}$ Reference category is single family status.

${ }^{3}$ Reference category is job tenure of more than 8 years. Sample size: $N=3488 ; N * S=10386$ Significance levels: $10 \%(*), 5 \%(* *), 0.1 \%(* * *)$

${ }^{3}$ Reference category is job tenure more than 8 years. 
Job quality, search and wealth

\section{References}

ABbring, J. AND G. VAN DEN BERG (2003): "The Nonparametric Identification of Treatment Effects in Duration Models," Econometrica, 71, 1491-1517.

- (2007): "The unobserved heterogeneity distribution in duration analysis," Biometrika, 94, 87-99.

Ai, C. AND E. NorTON (2003): "Interaction terms in logit and probit models," Economics Letters, 80, 123-129.

Aldy, J. AND K. Viscusi (2003): “The Value of a Statistical Life," Journal of Risk and Uncertainty, 27, 5-76.

Algan, Y., A. Chéron, J.-O. Hairault, and F. Langot (2003): "Wealth Effect on Labor Market Transitions," Review of Economic Dynamics, 6, 156178.

BLOOM, N. AND J. VAN REENEN (2010): "Human resource management and productivity," in Handbook of Labor Economics, ed. by O. Ashenfelter and D. Card, Elsevier, vol. 4.II, 1697-1767.

Bonhomme, S. And G. Jolivet (2009): "The Pervasive Absence of Compensating Differentials," Journal of Applied Econometrics, 24, 763-795.

Burdett, K. And D. Mortensen (1998): "Wage Differentials Employer Size and Unemployment," International Economic Review, 39, 257-273.

CLARK, A. (2001): "What really matters in a job?" Labour Economics, 8, 223242.

Clark, A. And B. Apouey (2013): "Winning Big but Feeling No Better? The Effect of Lottery Prizes on Physical and Mental Health," mimeo.

DANFORTH, J. (1979): On the role of consumption and decreasing absolute risk aversion, North Holland.

Freeman, R. (1978): “Job Satisfaction as an Economic Variable," American Economic Review, 68, 135-141.

GiElen, A. (2013): "Repeated Job Quits: Stepping Stones or Learning about Quality?" The IZA Journal of European Labor Studies, 2.

Gomes, J., J. Greenwood, And S. Rebelo (2001): "Equilibrium Unemployment," Journal of Monetary Economics, 1, 109-152. 
Job quality, search and wealth

Gronberg, T. AND R. ReED (1994): "Estimating Workers' Marginal Willingness to Pay for Job Attriubtes Using Duration Data," Journal of Human Ressources, 29, 911-931.

Hamermesh, D. (1977): Economic Aspects of Job Satisfaction, Wiley: New York.

HaYwood, L. (2011): "Watch your Workers Win. Changing Job Demands and HRM Responses," Management Revue, 22, 47-64.

Heckman, J. AND B. Singer (1984): "A Method for Minimizing the Impact of Distributional Assumptions in Econometric Midels for Duration Data," Econometrica, 52, 271-320.

Henley, A. (2004): "House Price Shocks, Windfall Gains and Hours of Work: British Evidence," Oxford Bulletin of Economics and Statistics, 66, 439-456.

Hwang, H., D. T. Mortensen, And W. R. Reed (1998): "Hedonic Wages and Labor Market Search,” Journal of Labor Economics, 16, 815-847.

Imbens, G., D. Rubin, And B. Sacerdote (2001): "Estimating the Effect of Unearned Income on Labor Earnings, Savings, and Consumption: Evidence from a Survey of Lottery Players," American Economic Review, 91, 778-794.

KNIESNer, T., K. Viscusi, C. WoOcK, AND J. ZiLiaK (2012): "The Value of a Statistical Life: Evidence from Panel data," Review of Economics and Statistics, 94, 74-87.

Kuhn, P., P. Kooreman, A. Soetevent, and A. Kapteyn (2011): "The Effects of Lottery Prizes on Winners and Their Neighbors: Evidence from the Dutch Postcode Lottery," American Economic Review, 101, 2226-2247.

Lentz, R. And T. Tranaes (2005): "Job Search and Savings: Wealth Effects and Duration Dependence," Journal of Labor Economics, 23, 467-490.

LindH, T. AND H. OHLSSON (1996): "Self-Employment and Windfall Gains: Evidence from the Swedish Lottery," Economic Journal, 106, 1515-1526.

LisE, J. (2013): "On-the-job search and precautionary savings," Review of Economic Studies, 80, 1086-1113.

Mortensen, D. (1986): “Job Search and Labor Market Analysis," in Handbook of Labor Economics, ed. by O. Ashenfelter and R. Layard, Elsevier, vol. 11, 849-919. 
Job quality, search and wealth

PiketTy, T. (2009): “On the Long-Run Evolution of Inheritance: France 18202050," mimeo.

Postel-Vinay, F. AND J.-M. Robin (2002): "Equilibrium Wage Dispersion with Worker and Employer Heterogeneity," Econometrica, 70, 2295-2350.

Rosen, S. (1986): "The Theory of Equalizing Differentials," in Handbook of Labor Economics, ed. by O. Ashenfelter and R. Layard, Elsevier, vol. 1, 641-692.

TAYLOR, M. (2001): "Self-Employment and Windfall Gains in Britain: Evidence from Panel Data," Economica, 68, 539-565.

VAN DEN BERG, G. (2001): "Duration Models: Specification, Identification, and Multiple Durations," in Handbook of Econometrics, ed. by J. Heckman and E. Leamer, Elsevier, vol. 5.

VAN DEN BERG, G. AND B. DREPPER (2011): "Inference for Shared-Frailty Survival Models with Left-Truncated Data," IZA Discussion Paper, 6031.

VAN Ommeren, J., G. VAn DEN Berg, And C. Gorter (2000): "Estimating the marginal willingness to pay for commuting," Journal of Regional Science, $40,541-563$. 